Int. J. Dev. Biol. 57: 319-332 (2013)

doi: $10.1387 / \mathrm{ijdb} .130020 \mathrm{re}$

\title{
Role of stem cell proteins and microRNAs in embryogenesis and germ cell cancer
}

\author{
RONAK EINI, LAMBERT C. J. DORSSERS and LEENDERT H. J. LOOIJENGA* \\ Erasmus MC, University Medical Center Rotterdam, Department of Pathology, The Netherlands
}

\begin{abstract}
Embryonic stem (ES) cells are pluripotent cells derived from the inner cell mass of the blastocyst. These cells can proliferate indefinitely and differentiate into all cell lineages. Germ cell cancers (GCC) mimic embryonic development to a certain extent. The origin of GCC trace back to primordial germ cells/gonocytes in the embryo, which determines their specific characteristics such as totipotency and overall (exceptional) sensitivity to DNA damaging agents. Thus GCC provide a useful model system for the study of gene regulation involved in oncogenesis as well as development. Several reports have demonstrated the role of specific proteins and microRNAs (miRs) in the control of pluripotency and thus early development. miRs are small non-coding RNA molecules that post-transcriptionally regulate gene expression by base-paring to protein encoding mRNAs. miRs are predicted to regulate up to $30 \%$ of the protein-encoding genes within the human genome. They are expressed in a tissue-specific and developmentally regulated manner. Aberrant miR expression and its correlation with development and progression of cancers is an emerging field. Important evidences have shown that knock-down by synthetic anti-sense oligonucleotides or re-expression of specific miRs by pre-miR can induce drug sensitivity, leading to increased inhibition of cancer cell growth, invasion, and metastasis. In addition, miRs have been found in body fluids of patients with different types of diseases, including cancer. Therefore, investigation of miRs can shed light on the process of pathogenesis, and may provide biomarkers for diagnosis and prognosis. A subset of miRs is specifically expressed in ES cells and GCC, suggesting their critical role in early embryogenesis and development. In this review we discuss the current view of the biology of embryonic stem cell proteins and miRs in GCC, and their potential clinical impact.
\end{abstract}

KEY WORDS: embryonic stem cell, embryogenesis, microRNA, germ cell cancer

\section{Introduction}

During development of a multi-cellular organism processes of growth and differentiation are kept well-controlled, although not always in balance. Post-transcriptional control of gene regulation plays a key role in maintenance of this process by coordinating the functional effect of selected genes at specific moments in time and place. In early mammalian development from maturation of the germ cell lineage to initiation of gastrulation, the role of posttranscriptional regulation is particularly apparent since the rapid growth and the subsequent switch from unspecialized cells into specific cell types requires control on mRNA localization, stability and translation which all provide fundamental ways of gene regulation (Suh et al., 2004).

The first cell fate decision is initiated by cell polarization at the 8- to 16-cell stage, where inner and outer cells are differentiated from each other. Outer cells adopt the trophoblast lineage, whereas the inner cell population give rise to the inner cell mass (ICM, the collection of cells that eventually will generate the fetus) forming the embryonic tissues and the primitive endoderm. The process of gastrulation converts the epiblast into the three definitive germ layers of the embryo, as well as generating the extra-embryonic tissues. The trophectoderm represents the extra-embryonic trophoblast lineage which participates in the formation of visceral yolk sac and envelops the inner cell mass. The early stem cells within the ICM begin to proliferate rapidly, ensuring that stocks of unspecialized cells are established for future differentiation into the three germ layers (Kuckenberg et al., 2011, Lu et al., 2009, Tremblay et al., 2001).

Abbreviations used in this paper: ES, embryonic stem cell; GCC, germ cell cancer; miR, micro RNA.

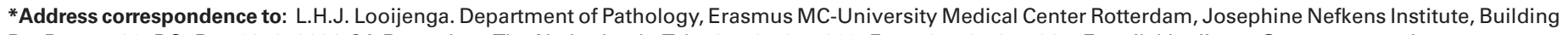
Be, Room 432, P.O. Box 2040, 3000 CA Rotterdam, The Netherlands. Tel: +31-10-7044-329; Fax: +31-10-7044-365. E-mail: I.looijenga@erasmusmc.nl
}

Final, author-corrected PDF published online: 5 June 2013.

ISSN: Online 1696-3547, Print 0214-6282 
In fact, from the fully grown oocyte stage until the moment of Zygotic Genome Activation (ZGA), the genome is transcriptionally silent (Suh et al., 2004). Therefore, all mRNA functionality regulation must occur post-transcriptionally (Lu et al., 2009). One group of post-transcriptional regulators are miRs. These small non-coding RNAs range in size from 18 to 32 nucleotides in length and have emerged in the past decades as major players in posttranscriptional regulation in many multi-cellular organisms (Alvarez-Garcia and Miska, 2005). Hundreds of miRs have been identified in worms, flies, fish, frogs, mammals and flowering plants using molecular cloning and bioinformatics prediction strategies (Lim et al., 2003, Reinhart et al., 2002, Watanabe et al., 2005) The first two miRs, lin-4 and let-7, were both initially identified based on their mutant phenotypes in forward genetic screens in the nematode Caenorhabditis elegans (Lee et al., 1993, Reinhart et al., 2000). Mutations causing loss of function in either lin-4 and let- 7 result in defective development but at different developmental stages (Wienholds and Plasterk, 2005). After this observation, it has been reported that proper embryonic development, indeed requires a well-organised temporal and spatial expression of miR besides expression of celltype specific genes (Chen, 2005, Karp and Ambros, 2005, Mineno et al., 2006). In general, it can be concluded that miRs are involved in the regulation of all different processes, including cell division, cell differentiation and cell death. Therefore, based on the fact that miRs interfere with the translation of mRNAs or proteins, it was predicted that aberrant miR expression might be found in cancer (Alvarez-Garcia and Miska, 2005, Wienholds and Plasterk, 2005).

\section{miRNA biogenesis and mechanism}

The miRs are transcribed as long RNA precursors (pri-miR) that contain a stem-loop structure of about 80 bases. These pri-miRs are processed in the nucleus by the RNase III enzyme Drosha and DGCR8/Pasha, which form the microprocessor complex and process long pri- miRs into short hairpins called precursor miRs (pre-miR). The pre-miRs are exported from the nucleus by Exportin-5 (Landthaler et al., 2004, Lee et al., 2003, Lund et al., 2004). In the cytoplasm, another RNase III enzyme, Dicer, cuts the pre-miR to generate the mature miR as part of a short RNA duplex. The RNA is subsequently unwound by a helicase activity and incorporated into a RNA-induced silencing complex (RISC). At this stage, miR can mediate down-regulation of target gene activity by two modes: translational inhibition or target mRNA cleavage. The choice is made based on the degree of complimentarity between the miR and target gene in combination with an Argonaute family protein. Near-perfect complementarity results in cleavage, followed by general RNA degradation of the targets, whereas partial complementarity causes translational inhibition (Wienholds and Plasterk, 2005).

\section{Embryonic stem/germ cells and pluripotency}

ES cells are capable of indefinite self-renewal as well as generating all cell-types within the body (pluripotency). These capacities of ES cells require unique transcriptional and cell cycle regulations (Jaenisch and Young, 2008). Gene expression analysis in the early embryo has led to the identification of several factors that may be involved in the regulation of early developmental events. These include genes encoding growth factors, their receptors and numer- ous transcription factors, among which pluripotency factors seem to play major role (Ovitt and Scholer, 1998). In this review, we will discuss predominantly three master pluripotency factors: OCT3/4, NANOG and SOX2. They function in combinatorial complexes to regulate the pathways involved in ES cell pluripotency and cellular differentiation: OCT3/4 (also known as POU5F1) is a POU-domain, octamer binding transcription factor, expressed in both mouse and human ES cells. OCT3/4 is critical for the maintenance of pluripotency in ES cells and is down-regulated in all differentiated somatic cell types in vitro as well as in vivo (Pesce and Scholer, 2001). Oct3/4 expression starts at the morula stage and becomes restricted at first to the inner cell mass during blastocyst formation, subsequently to the epiblast during gastrulation and finally to primordial germ cells (PGC) (Rosner et al., 1990, Scholer et al., 1989). PGC lacking Oct3/4 expression has been shown to undergo apoptosis rather than differentiation (Boiani et al., 2004).

However, OCT3/4 is not the only key gene regulating ES cell and germ cell pluripotency. The homeodomain protein Nanog is also required for the maintenance of pluripotency in the inner cell mass in vivo (Mitsui et al., 2003). Nanog plays a critical role in regulating the cell fate of the pluripotent epiblast and preventing differentiation to primitive endoderm. In addition, down-regulation of Nanog can induce both mouse and human ES cell differentiation to extra-embryonic lineages (Pan and Thomson, 2007). Nanog mRNA is also enriched in pluripotent germ cells. Similarly, Nanog deficiency in PGC triggers apoptosis but not cell differentiation (Yamaguchi et al., 2009). Another key pluripotency regulating gene is SOX2. The SOX2 expression factor is a member of the SRYrelated HMG box transcription factor family. SOX2 is expressed in pluripotent cells and multi-potent embryonic and extra-embryonic cells. Sox 2 cooperates with Oct3/4 to activate the expression of a number of genes that regulate pluripotency including Nanog (Masui et al., 2007). This appears essential for the derivation of induced pluripotent stem cells from primary human fibroblasts (Huangfu et al., 2008). Interestingly, priming by Nanog results in improved capacity to generate iPS cells.

We demonstrated that SOX2 is not present in human germ

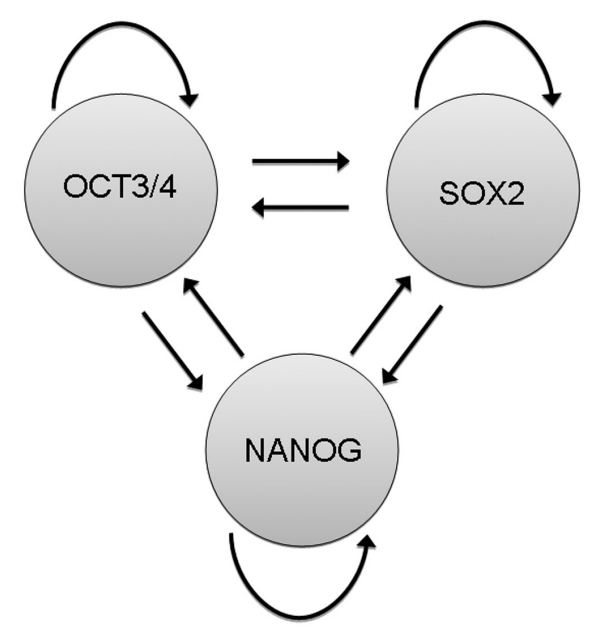

Fig. 1. Schematic interconnections between OCT3/4, SOX2 and NANOG. The core ES cell regulators form intrinsic self-regulatory and feed-back loops at the transcriptional and translational level to insure high expression levels and self-stabilizing system for the maintenance of pluripotency in mouse and human ES cells. 
cells, in contrast to mouse (see below), but instead another member of the SOX family, SOX17, is expressed in human germ cells and their malignant counterparts (de Jong et al., 2008). Knock-out studies and expression data of SOX17 in primitive endoderm, fetal human stem cells, and early germ cells indicate a crucial role for this transcription factor in a number of lineages during embryonic and fetal development (Kanai-Azuma et al., 2002). Sox2 has shown to be present in PGC and gonocytes (testis and ovary) of mouse whereas it is absent in human embryonic gonads. (Perrett et al., 2008). An interesting hypothesis to be tested is that the protein complex containing OCT3/4 and SOX17 is predominantly involved in regulation of cell death and OCT3/4 and SOX2 in differentiation.

These three transcription factors interact physically with each other and occupy regulatory regions in many target genes towards the regulation of pluripotency. Oct3/4, Sox2 and Nanog co-occupy several hundred genes, often at overlapping genomic sites suggesting that these pluripotency factors generally do not control their target genes independently, but rather act co-ordinately to maintain the transcriptional program required for pluripotency. Furthermore, Oct3/4, Sox2 and Nanog are also bound to their own promoters forming an inter-connected auto-regulation loop to maintain the ES cell identity (Boyer et al., 2005, Loh et al., 2006). This is schematically illustrated in Fig. 1.

\section{Induced pluripotent stem cells}

Regarding the mentioned facts about the critical role of pluripotency factors in ES cells, in 2006, Takahashi and Yamanaka demonstrated that differentiated cells can be converted into so-called induced pluripotent stem cells (iPS cells) by forced expression of four transcription factors Oct3/4, Sox2, Klf4 and c-Myc, which have been termed Yamanaka factors (Takahashi and Yamanaka, 2006). Recently, in a similar approach towards converting somatic cells into pluripotent cells two independent groups (Miyoshi et al., 2011; Anokye-Danso et al., 2011) have reported that mouse and human somatic cells can be reprogrammed to pluripotency by introducing embryonic stem cell miR, miR-302 family and miR-367. It is also reported that introduction of another group of embryonic stem cell specific miR, miR-291-5, enhances production of mouse iPS cells. The miR-291-3p, miR-294 and miR-295, a dominant miR cluster in mouse ES cells with a role in promoting cell proliferation and maintaining pluripotency, increase the efficiency of reprogramming by Oct3/4, Sox2, Nanog and Klf4 (Judson et al., 2009).
These evidences emphesis on the crucial role of ES cell miR in cell cycle, pluripotency, differentiation and early development of a multicellular organism.

\section{Embryonic stem cell microRNAs}

So far, a total of 678 miRs within human genome and 472 miRs within the mouse genome have been discovered, but only a subset of these miRs is expressed in ES cells. So far, $31 \mathrm{miRs}$ have been reported to be ES cell specific (Morin et al., 2008, Suh et al., 2004, Wang et al., 2009). In this review, we focus on two ES miR clusters: miR-371-3 cluster (the human counterpart of miR-290-295) and miR302a-d/367 cluster.

The overall roles of miRs in both mouse and human ES cells have been evaluated by analyzing the phenotypes of Dicer and Dgcr8 mouse mutants (Liu et al., 2011, Liu and Tang, 2011). Dicer-deficient mouse ES cells exhibit defects in differentiation and $\mathrm{G}_{1}$ cell-cycle arrest (Kanellopoulou et al., 2005). Moreover, deletion of Dicer causes embryonic lethality (Bernstein et al., 2003). Similarly, Dgcr8deficient mouse ES cells show problems in cell-cycle progression and differentiation, evidenced by failing to silence self-renewal genes, such as Oct3/4, Nanog and Sox2, as well as delayed expression of differentiation markers (Liu et al., 2011). The Dgcr8knockout ES cell phenotype differs from Dicer1 knockout. Both knockouts are defective in differentiation. Dicer1 knockout ES cells have more severe initial proliferation defect that is overcome over time possibly due to additional genetic events, however, Dgcr8 knock-out ES cells show a stable and more subtle proliferative defect (Kanellopoulou et al., 2005, Wang et al., 2007). These overall miR-deficient cells showed a relative increase in the number of cells in the $G_{1}$ phase of the cell cycle. This finding suggests that miR suppress inhibitors of the $G_{1}-S$ transition, allowing the rapid transition from mitosis to $S$ phase (Wang et al., 2008). These evidences demonstrate the crucial role of miR in ES cell self-renewal and differentiation. How $\mathrm{miR}$ regulates gene expression in ES cells is described recently (Marson et al., 2008), indicating that the key ES cell transcription factors are associated with promoters for miRs that are expressed in ES cells. In fact, miR promoters are occupied by master ES cell transcription factors, including OCT3/4, SOX2 and NANOG. This suggests an important role of ES cell miRs in the maintenance of the pluripotent cell state, as summarized in Fig. 2.

On the other hand, miRs can regulate expression of pluripotency genes by binding to their coding regions. A good example
Fig. 2. Embryonic stem (ES) cell self-renewal and differentiation. ES cells have the ability to self-renew or differentiate into cells of all three germ layers (endoderm, ectoderm, and mesoderm). In ES cells, OCT3/4, SOX2, and NANOG form a core transcriptional network influencing the stem cell self-renewal machinery. The interaction of downstream miRs and protein coded genes with these master ES cell transcriptional factors and their opposing functions play major role in the properties of ES cells.

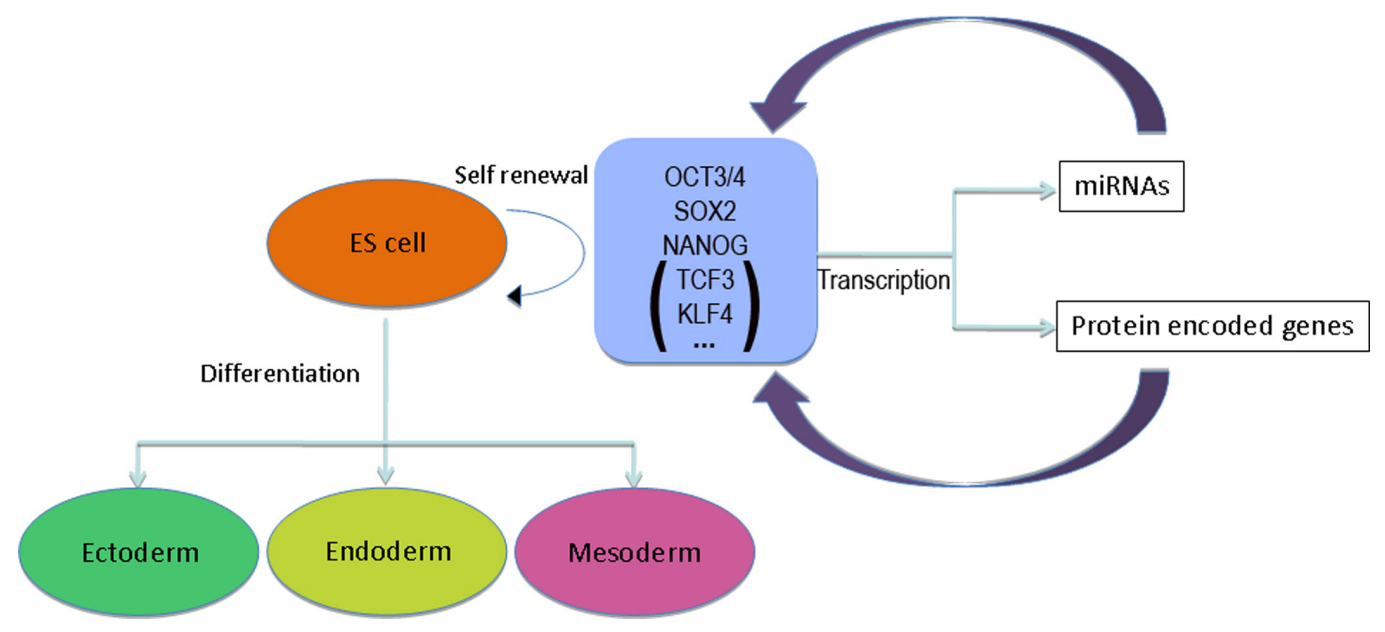


for regulatory circuitry between miRs and pluripotency genes is the one between Lin28 and let-7 miR. Lin-28, a marker of ES cells, also forms a negative feedback loop with the let-7 family miR to control each others levels. Lin-28 regulates expression of let-7 by binding to the precursors and blocking their maturation, whereas in differentiated cells where let-7 levels are increased, let-7 miR targets the Lin-28 mRNA (Liu et al., 2011).

\section{Germ cell tumor biology in summary}

Malignant germ cell tumors are the most frequent malignancy in Caucasian males between 20 and 40 years of age, and the first cause of cancer death in this age group with increasing incidence (Huyghe et al., 2007, Shah et al., 2007). Human germ cell tumors are a heterogeneous group of neoplasm occurring in gonads, both testes and ovaries, and in different extra-gonadal sites along the midline of the body and the midline of the brain. The specific characteristics can either be due to the process of tumorigenesis or just a reflection of normal embryonal development, which contributes to the complexity of these tumors. Based on epidemiology, phenotypic characterization, chromosomal constitution and genomic imprinting, the group of testicular germ cell tumors comprises three types mainly: Type I, II and III. In the context of the role of ES cell miRs, predominantly the Type I and II will be discussed. Type I germ cell tumors are the teratomas and yolk sac tumors occurring in newborn and infants. The type II germ cell tumors comprise the seminomatous tumors (seminoma (SE)/dysgerminoma (DG) /germinoma) and nonseminomatous tumor, referred to as the malignant germ cell tumors, i.e., germ cell cancers (GCC). The non-seminomas are subdivided into embryonal carcinoma (EC, undifferentiated stem cell component, similar to ES) and the various derivatives: extraembryonic lineages (yolk sac tumor (YS) and choriocarcinoma) and along the somatic lineage (teratoma) (Looijenga et al., 2007,

\section{ES cell like}

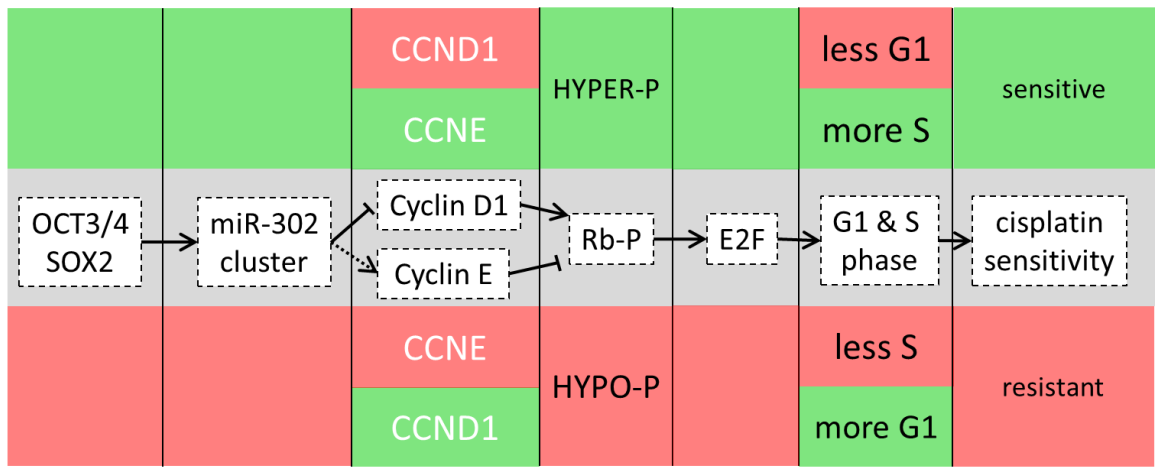

\section{Differentiated cells}

Fig. 3. Schematic presentation of $\mathbf{G}_{\mathbf{1}}-\mathbf{S}$ transition in $\mathbf{E S}$ cells and somatic cells. In ES cells, high expression of OCT3/4 and SOX2 maintains high expression level of miR-302 cluster causing hyper-phosphorylation of Rb via directly suppression of Cyclin D1 directly and activation of Cycin $E$ resulting in high expression of E2F protein. This causes short $G_{-}-S$ phase by accumulating more cells in $S$ phase and less in $G_{1}$. This will lead to sensitivity of ES cells to cisplatin. In differentiated (somatic) cells low expression of main pluripotency factors results in lower expression level of miR-302 cluster leads to hypo-phosphrylation of Rb via up-regulation of cyclin D1 (green) and down-regulation of cyclin E. Rb then inhibits E2F protein. This will cause long $G_{1}-S$ due to accumulation of more cells in $G$, and less cells in $S$ phase, and consequently result in a more resistant type of differentiated cell to cisplatin. Abbreviations and colors used: Red=low protein/ miR; green=high protein/miR; hyper- $P=$ hyper phosphorylation; Hypo- $P$ = hypophosphorylation
Oosterhuis and Looijenga, 2005). The precursor cells of GCC are own as carcinoma in situ (CIS) or intratubular germ cell neoplasia either PGC or gonocyte, blocked in its physiological maturation imprinting is the phenomenon that the paternal and mater of chromosomes have different functionality in mammals, due to parental-specific epigenetic modification. This modification is established somewhere between the stage of a PGC and a spermatozoa (male) and an oocyte (female) (McLaren, 2003, Oosterhuis and Looijenga, 2005). The functional difference between the paternal and maternal haploid set of chromosomes comes from so-called mprinted genes, which are expressed from the paternal or materna testicular GCC, in line with their erased embryonic germ cell (van Gurp et al., 1994). is related to epigenetic modifications of the genome, including DNA modification (Hajkova et al., 2002). This known as spermatocytic seminomas (SS). They have shown to have a different cell of origin, i.e., spermatogonia/spermatocyte. These e characterized by a different pattern of chromosomal anomalies, ( spermatogonia/spermatocyte.

OCT3/4 is the most informative diagnostic marker in recognizing CIS/GB, as well as SE/DG and EC (Looijenga et al., 2003). In contrast, SOX2 is expressed in EC, but not the precursor lesions and SE and normal germ cells, while it is more heterogeneous in the differentiated nonseminomatous elements (de Jong et al., 2008). On the other hand, SOX17 is a suitable marker to distinguish SE (positive) from EC (negative) (de Jong et al., 2008, Korkola et al., 2006). Moreover, LIN-28 is expressed in precursor lesions (both CIS and GB), as well as SE/DG, EC and yolk sac tumor (YS). In addition, elevated level of TSPY has been observed in a variety of tumor tissues, including GCC (Oram et al., 2006). Testis-specific- protein Y-encoded (TSPY) is a multi-copy gene mapped to the critical region harbouring the gonadoblastoma locus on the Y chromosome, the only proven oncogenic locus on the male-specific chromosome(Oram et al., 2006). The genetic interaction of TSPY and GB has been clinically established (Page, 1987). In testicular GCC patients as well as in model cell lines, co-expression of TSPY and androgen receptor (AR) is observed whereas such co-expression was not seen in normal testis of human or mouse (Akimoto et al., 2010). In addition, TSPY is suggested to induce an 
anti-androgenic microenvironment, possibly leading to a block in maturation of germ cells. This indicates that co-expression of TSPY and OCT3/4 is informative to detect CIS cells from delayed matured germ cells.

\section{p53 in ES cells and GCC}

Since extensive proliferation and differentiation of stem cells can contribute to hyper-proliferative disorders, a coordinated control of stem cell self-renewal and differentiation is fundamental for maintaining tissue and organ homeostasis. p53 appears to contribute to this process by controlling the proliferation, self-renewal and differentiation of both embryonic and adult stem cells. The first observation about a potential role of p53 in ES cells was reported in 1980 (Mora et al., 1980) in which they observed that p53 was highly expressed in primary cell cultures obtained from 12-14 day old mouse embryos but not in cells from 16 day old embryos. In differentiated cells, p53 is an important regulator of cell proliferation. By controlling expression of the p21 gene, which encodes the inhibitor of cyclin-dependent kinases, p53 induces transition from $G_{1}$ into S-phase of the cell cycle. In addition, p53 is able to initiate apoptosis by both the extrinsic and intrinsic pathways. In concordance with these activities in differentiated cells, p53 also controls proliferation and cell death in ES cells. Treatment of human ES cells with nutlin, an inhibitor of p53 degradation, leads to the rapid accumulation of $p 21$ and to cell cycle arrest at the $G_{1} / S$ boundary (reviewed in Solozobova and Blattner, 2011). Interestingly, it is shown that knock-down of p53 in human adult fibroblast has dramatically increased the efficiency of iPS cell generation (Zhao et al., 2008).

The presence of functional p53 in undifferentiated ES cells makes them hypersensitive to UV irradiation, whereas the differentiated cells were resistant to UV treatment. Wild-type ES cells undergoing apoptosis expressed functional p53 whereas ES cells lacking p53 showed enhanced proliferation in both undifferentiated and differentiated state and apoptosis was reduced. Undifferentiated ES cells with a functional p53 protein proliferate slower than p53-/-

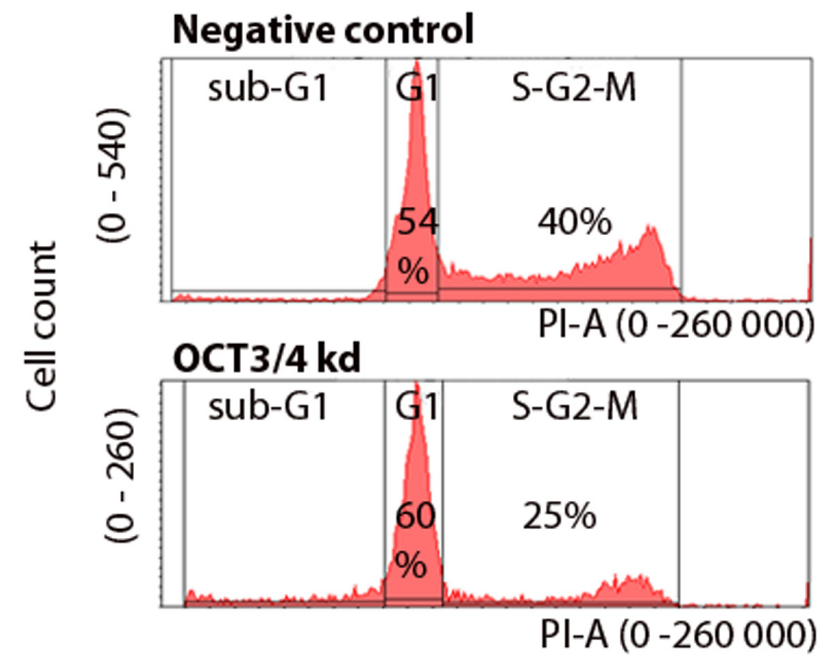

Fig. 4. Result of FACS analysis. NTera-2 cells were subjected to OCT3/4 siRNA and scrambled siRNA (negative control). As it is indicated in OCT3/4 kd situation, more cells are accumulated in $G_{1}$ phase and less cells are in $S$ phase compare to negative control.
ES cells. This indicates that functional p53 is involved in regulating proliferation of these cells in vitro (Sabapathy et al., 1997). This is related amongst others, to induction of pre-mature senescence after oncogenic stress. These observations could explain why genes that are involved in the establishment of oncogene-induced senescence such as p53 are amongst the most tumor suppressor mutated genes in tumor formation. However, GCC are an exception to this rule. They have been shown to express wild-type p53 and mutations in this protein are rare while they proliferate fast and respond to DNA damaging agents, such as cisplatin (in most cases) (Kersemaekers et al., 2002 , Masters and Koberle, 2003).

\section{ES cell division}

ES cells have a unique cell cycle characterized by lack of $G_{0}$, absence of $G_{1}$ checkpoint and subsequently a short $G_{1} / S$ transition which facilitates quick cell movement through $G_{1}$ to $S$ phase allowing the cells to proliferate rapidly leading to rapid growth of the early embryo (He et al., 2009). This specific characteristic of ES cells makes these cells hypersensitive to DNA damaging agents. In recent studies, miRs have shown to play a central role in achieving this unique cell cycle regulation (Hong and Stambrook, 2004, Wang et al., 2009). In somatic cells, where the $G_{1} / S$ checkpoint exists, the $\mathrm{G}_{1}$ phase is a gap period between cytokinesis and DNA replication. During the early $G_{1}$ phase, upon stimulation of the mitogenic factors, $D$-type cyclins are expressed. These cyclins are required during $G_{1}$ restriction point to activate the $\mathrm{Cdk} 4 / 6$ and the $\mathrm{Cdk} 2$ kinases which are expressed throughout cell cycle. The Cdk4/6-Cyclin D complex then phosphorylates proteins of the retinoblastoma $(p R B)$ family. This leads to the partial inhibition of RB and release of its target, the E2F transcription factor. Upon elevation of E2F, the expression of E-type Cyclin increases resulting in activation of Cdk2 which further phosphorylates RB. This event leads to the transcription of genes required for progression through the $S$ phase. This will result in the elongation of $G_{1}$ phase and slower proliferation of the resulting somatic cells (Wang et al., 2009, White et al., 2005) (Fig. $3)$. Aberration in the expression of cell cycle regulatory factors can lead to uncontrolled proliferation which is one of the hallmarks of cancer (Hanahan and Weinberg, 2000). In conclusion, ES cells characterized by a very short $\mathrm{G}_{1}$ phase and lack of a check point at the $G_{1} / S$ transition, are very similar to many cancer cells (Wang et al., 2009). In this context, it is shown that ectopic expression of TSPY increases cell proliferation in vitro and tumorigenesis in vivo (Oram et al., 2006). Expression of TSPY facilitates the transition of the cells through the $\mathrm{G}_{2} / \mathrm{M}$ phase of the cell cycle, indirectly up-regulates pro-growth genes and down-regulates apoptosis inducing molecules and growth inhibitory genes, thereby promoting cell proliferation in both in vitro and in vivo. TSPY harbours a SET/ NAP domain represented by the SET oncoprotein and nucleosome assembly protein-1 (NAP-1) respectively. Several evidences have shown that SET/NAP-containing proteins are cell cycle regulators. They regulate the $\mathrm{G}_{2} / \mathrm{M}$ transition by modulating cyclin-B-cyclindependent kinase 1 (CDK1) activity (Canela et al., 2003).

\section{Potential role of miR-290 and miR-302 clusters in em- bryonic stem cell division}

In a study in which identification of the specific miR and targets involved in the process of rapid transition from mitosis to $S$ phase 
was aimed, it was found that introducing specific miR mimics in the Dgcr8 knockout ES cells, could promote growth and partially rescued the proliferation defect in these cells. In that study, miR290 cluster which is the most highly expressed miR in mouse ES cells and rapidly down-regulated upon differentiation, was selected (Calabrese et al., 2007). Moreover, in another study, by adding back individual miR into Dgcr8 knockout ES cells, many miRs, including members of the miR-290 and miR-302 clusters, were found to rescue the prolonged $G_{1}$ phenotype by reducing cells accumulation in $S$ phase or $G_{2}-M$ phase. These data show that $E S$ cell-specific miRs promote $E S$ cell proliferation at least in part by promoting the transition of cells from $G_{1}$ to $S$ phase. These miRs are called ES cell-specific cell cycle-regulating miRs or ESCC miRs (Wang et al., 2008).

It has been reported that expression of miR-302a caused decrease in the number of cells in $G_{1}$ phase and increased the population of cells in S-phase and $\mathrm{G}_{2} / \mathrm{M}$-phase in HeLa cells transfected with Pre-miR-302a compared to the cells transfected with negative control pre-miR. Therefore, consistent with the previous reports, in pluripotent human ES cells, the majority of cells were in S-phase and as cells progressively differentiate, the cell cycle profile shifts from a short $G_{1}$ /high $S$-phase population to a high $G_{1}$-phase cell cycle and this shift is mediated through miR-302 decrease of cell cycle regulator level in pluripotent cells (Card et al., 2008). In the same study, similar increase in the population of $\mathrm{G}_{1}$-phase of NTera2 (an EC cell line of GCC origin) cells which have been differentiated with retinoic acid is detected. Interestingly, in an experiment done in our lab, we observed that accumulation of differentiated NTera2 cells in S phase was reduced when subjected to OCT3/4 siRNA followed by increasing cell population in $\mathrm{G}_{1}$-phase analyzed by Fluorescence Activated Cell Sorting (FACS) confirming their ES characteristics (Fig. 4). When ES cells differentiate, $G_{1}$ phase lengthens and the rate of cell division slows (He et al., 2009). We tested the combined down-regulation of OCT3/4 and SOX2 in NT2,

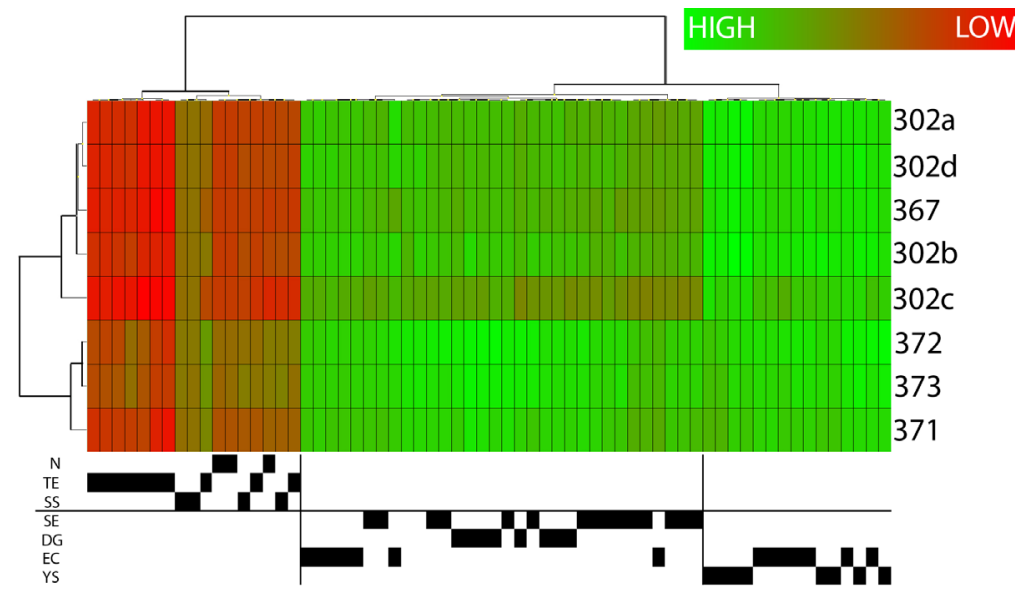

Fig. 5. Results of the unsupervised hierarchial clustering. miR clusters miR-371-3 and miR-302/367 are differentially expressed between different subtypes of GCC, highly expressed in SE/DG and EC and absent in teratoma (TE), SS and normal testis parenchyma (NT). The numbers of each histological subtype are indicated: (SE $\left.{ }_{n=15}\right)$, $\left(E C_{n=13}\right),\left(Y S_{n=8}\right),\left(T E_{n=10}\right),\left(S S_{n=4}\right),\left(D G_{n=10}\right)$ and (NT $\left.{ }_{n=3}\right)$. For normalization, all miRs on the plate were used using mean expression of all genes (threshold C40) according to (Mestdagh et al., 2009). Clustering was performed using Ward's algorithm; both dendrograms were formatted according to euclidean distance. GenEx 5.3.7.332 was used to analyze the data. and observed massive induction of apoptosis in these cells. This also confirms the major role of these core pluripotency factors in proliferation and cell cycle of EC cells.

\section{microRNAs in germ cell cancers}

We demonstrated that specific miRs are able to mimic the effect of mutated p53 and thereby bypass pre-mature senescence after oncogenic exposure (Voorhoeve et al., 2006). Using a high throughput unbiased functional screen, a cluster of miR mapped to chromosome 19, known as miR-371-3, was found to be responsible for this phenomenon, subsequently found to be expressed in almost all SE, EC as well as YS. Interestingly, a small number of SE with p53 mutation lacked expression of this set of miRs, and two GCC-derived cell lines with a low or no expression of these miRs showed either a mutated or non-expressed p53 supporting the proposed model. Therefore, miR-371-3 was considered a potential oncogene, able to mimic the effect of mutated p53 by preventing Ras-induced oncogenic senescence in GCC. This process is most likely occurring via suppression of CDK inhibitor LATS2 (Large tumor suppressor) which is the target of miR-371-3 (Voorhoeve et al., 2006).

Based on these findings, a high-throughput screen of $157 \mathrm{miRs}$ using a quantitative RT-PCR based approach in GCC was performed in which only the mature miRs were detected. First, indeed expression of the miR cluster 371-373 was confirmed. Secondly, unsupervised hierarchical clustering showed different expression of the cluster in different groups of tumors. miR-371-3 was highly expressed in SE, EC and YS, but not expressed in teratoma and normal testicular parenchyma (NT) (Fig. 5). In the same study, miR-302a-d cluster were differentially expressed between the clusters of GCC; highly expressed in SE and EC as well as YS and absent in teratoma (Gillis et al., 2007).

Additionally, in an independent study (Novotny et al., 2012) it was demonstrated that the miR-371-3 and miR-302/367 clusters were enriched in CIS samples while they were very low expressed or absent in the normal testis. This indicates that high expression of these miRs is not restricted to the invasive components, but intrinsic to the early pathogenetic stage. In addition, we have shown that no mutation, deletion or amplification was present in the loci of miR-371-3 and miR-302 clusters in the DNA of 242 GCC revealing that no genetic changes affect on the expression levels of these miR clusters (De Boer et al., submitted for publication).

\section{Expression levels of miR-371-3 and miR-302 clusters}

We measured expression of the individual members of the miR-371-3 and miR-302 clusters in a series of GCC cell lines and primary GCC (EC, SE and YS, teratoma, normal testis as well as SS). Comparing the patterns of expression, it is of interest that in almost all samples (cell lines and tumors), within the different clusters, the same variant was showing the highest level of expression: miR-372 and miR-302b and miR-302d, respectively (Fig. 6). Since all members of the two clusters are generated from a single primary transcript (see above), this observation can not be explained by differences in transcription, but are likely due to variation in maturation and/or stability of the mature transcript. This needs further investigation. 


\section{miR-371-3}

The miR-371-3 cluster and its murine ortholog, the ES cellspecific cell cycle regulating miR-290-5 cluster, are over-expressed in ES cells and down-regulated upon differentiation. These miRs play a crucial role in the maintenance of ES cell renewal (Stadler et al., 2010, Suh et al., 2004). They promote tumor invasion and metastasis in response to hypoxia (Huang et al., 2008, Voorhoeve et al., 2006). Recently, a direct regulation of the miR-371-3 cluster by Myc is reported (Cairo et al., 2010). This is of interest in the context of iPS cells because c-Myc in combination with other core pluripotency factors was used to generate iPS cells from a differentiated fibroblast (Takahashi and Yamanaka, 2006). Lack of c-MYC in this set up results in a significantly lower efficiency in the ability to generate iPS cells (Nakagawa et al., 2008, Wernig et al., 2008, Zhao et al., 2009). Moreover, as recently found for the murine ortholog miR-294 in ES cells (Melton et al., 2010), it is suggested that Myc is up-regulated by the miR-371-3 cluster. This might be due to the direct binding of the miR to the $M Y C$ genomic region or inhibition of an intermediate repressor or direct activation through binding. Moreover, miR-290-295 cluster is reported to be highly enriched in the germ cell population of day 6 testis when compared to the somatic cell population (Medeiros et al., 2011). This cluster is a target of pluripotency factors, and in turn targets the pluripotency factors Oct3/4, Sox2 and Nanog (Zheng et al., 2011). It is shown that suppression of the miR-290 cluster, besides embryonic lethality, leads to the defective migration of PGC numbers in the gonads. In addition, they are differentially expressed between gonocytes and spermatogonia pointing to their role in the differentiation of gonocytes. These data demonstrate the role of the miR-290 cluster in the maturation of germ cells, indicating that this miR cluster plays an important role in transition from gonocyte to spermatogonia and in the pre-invasive lesion CIS, which has been disrupted and failed to successfully differentiate into a spermatogonium (Mclver et al., 2012).

\section{miR-302/367}

The cluster of miR miR-302/367 represents the first human miR promoter characterized in human ES cells and their malignant counterpart EC cells (Barroso-delJesus et al., 2008, Suh et al.,
2004). The cluster miR-302-367 is located on chromosome 4 and contains eight different miRs: miR-302a, miR-302a*, miR-302b, miR-302b*, miR-302c, miR-302c ${ }^{*}$, miR-302d and miR-367. The first seven constitute the miR-302 family with a highly conserved sequence (Barroso-delJesus et al., 2008). The major members of the miR-302 family (302a, 302b, 302c and 302d) share a high sequence homology, differing only in the 3 'hexanucleotides. All four family members display a cytoplasmatic localization with no significant differences among them, meaning that the 3 'hexanucleotides does not promote nuclear localization for any of these miRs.

miR profiling has confirmed cell type specificity for miR-302/367 expression; it is highly expressed in human ES and EC cells but not in adult human mesenchymal stem cells (hMSCs) and normal tissues. The miR-302/367 promoter activity depends on the hierarchical cellular stage. The promoter activity is functional in human and mouse ES cells and human EC cells, but it is turned off later in development (Barroso-delJesus et al., 2008). miR-302/367 can target over 445 human genes and most of these targets are developmental signals involving the initiation and facilitation of lineage-specific cell differentiation during early human embryogenesis (Lin et al., 2008). miR-302/367 promoter activity decays upon differentiation of both mouse and human ES cells, demonstrating that its activity is restricted to the ES cell compartment and that the ES cell-specific expression of the miR-302/367 cluster is fully conferred by its core promoter transcriptional activity. Importantly, these data are further supported by the fact that endogenous miR$302 / 367$ expression is also down-regulated during human ES cell differentiation (Barroso-delJesus et al., 2008). The important point is that the key ES cell-specific factors such as, OCT3/4, SOX2 and NANOG act as upstream regulators of the miR-302/367 cluster meaning that potential binding sites for these pluripotency factors in the promoter sequence of these miRs are present (BarrosodelJesus et al., 2008, Card et al., 2008). It has been demonstrated that in human ES cells the expression of miR-302a under OCT3/4/ SOX2-depleted conditions was reduced by more than $50 \%$ in comparison with the level in cells transfected with non-targeting siRNAs. These data support the model that the expression of miR-302a is dependent on OCT3/4-SOX2 in human ES cells and suggest that OCT3/4 and SOX2 function as transcriptional activators (Card et
A

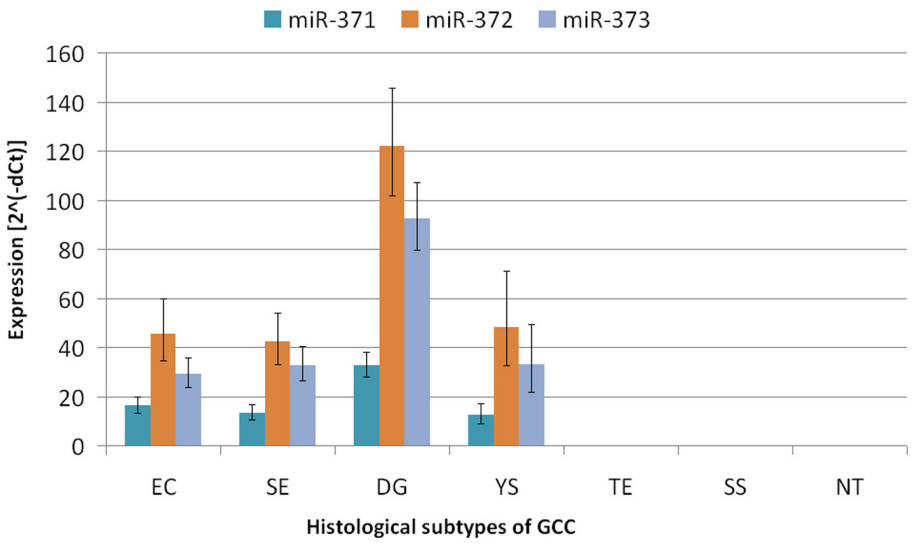

B

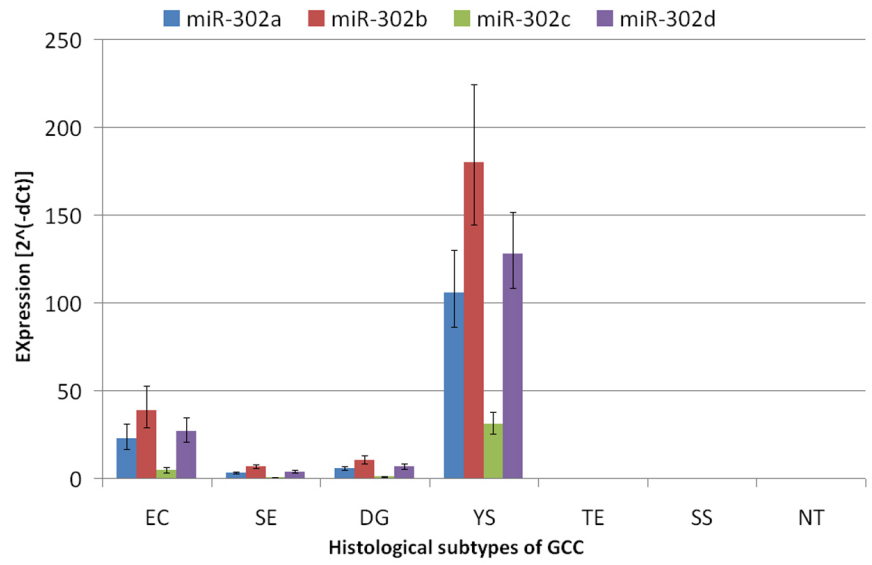

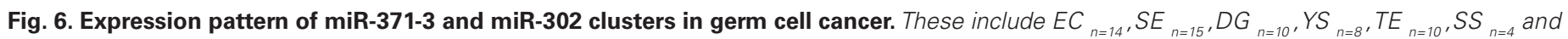

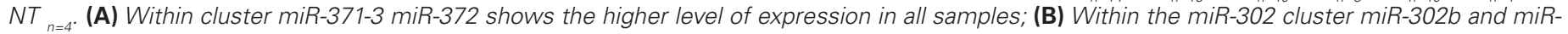
$302 d$ show the highest level of expression. (The CT values of miRs are normalized as described before (Mestdagh et al., 2009). 
al., 2008). Interestingly, siRNAs directed against OCT3/4 and SOX2 in a human EC cell line (NTera2) showed down-regulation of miR-302/367 cluster up to $50 \%$ in our experiment confirming the relationship between pluripotency and miR-302/367 cluster (shown in Fig. 7). This also confirms that initiation of differentiation reduces the level of miR-302/367 cluster in EC.

\section{miR-371-3 and 302/367 in other cancer types}

miR-371-3 and miR-302/367 have been reported to be involved in other malignancies than GCC. In a study regarding expression of miRs in oesophageal squamous cell carcinoma, it has been shown that miR-373 participates in the carcinogenesis of human oesophageal cancer by directly suppressing LATS2 expression (Lee et al., 2009). Additionally, in a study related to human hepatocellular carcinoma (HCC), it is found that miR-373 is up-regulated in HCC tissues as compared with adjacent normal tissues, and promotes the proliferation of $\mathrm{HCC}$ cell lines by regulating the $\mathrm{G}_{1}-\mathrm{S}$ transition (Wu et al., 2011). In a number of studies it is reported that miR-373 can promote tumor invasion and metastasis such as breast and prostate cancer (Huang et al., 2008, Negrini and Calin, 2008, Yang et al., 2009). Additionally, up-regulation of miR-373 in retinoblastoma has been reported (Zhao et al., 2009). Furthermore, miR-371-3 cluster has shown to be up-regulated in thyroid adenomas (Rippe et al., 2010). Up-regulation of miR-302/367 has been reported in glioblastoma multiforme. It is shown that this miR cluster is rapidly and strongly induced in glioma-initiating cells (Fareh et al., 2012). In addition, miR-302 is reported to be enriched in human leukaemia cell lines (Yu et al., 2006), large B cell lymphoma (Lawrie et al., 2009). miR-367 is also found to be increased in non-small-cell lung cancer (Campayo et al., 2012). Furthermore, miR-302 has been shown to reprogram human skin cancer cells into a pluripotent ES cell like state (Lin et al., 2008).

\section{Functional read-out system in GCC cell lines}

Considering all the mentioned facts about miR-371-3, we initiated a study in order to investigate the role of suppression of

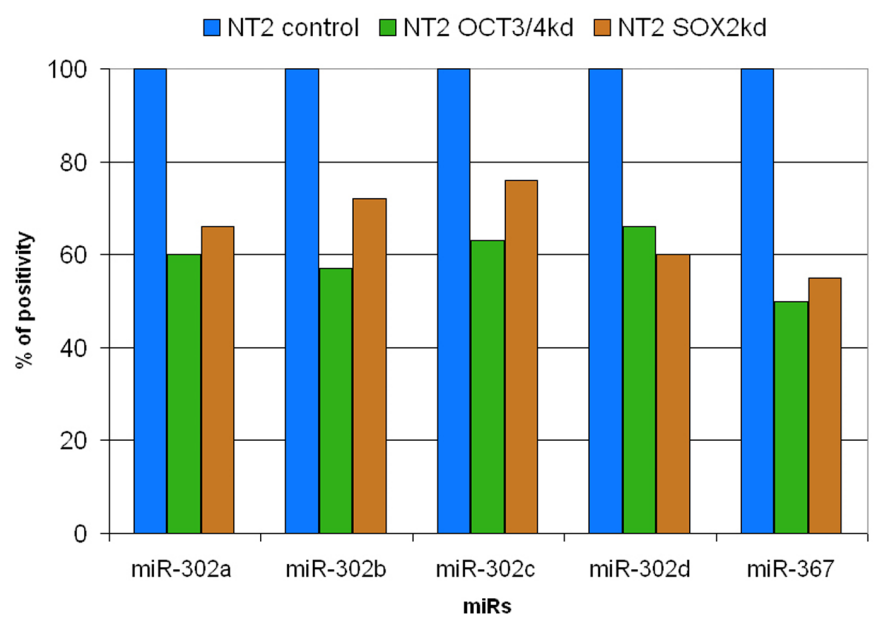

Fig. 7. High throughput results show down-regulation of expression of the members of cluster miR-302/367 due to OCT3/4 and SOX2kd in NTera2 cells. All miR members in the cluster show down-regulation $(\sim 50 \%)$ in cells subjected to OCT3/4 and SOX2 siRNA compare to cells transfected with scrambled siRNA.

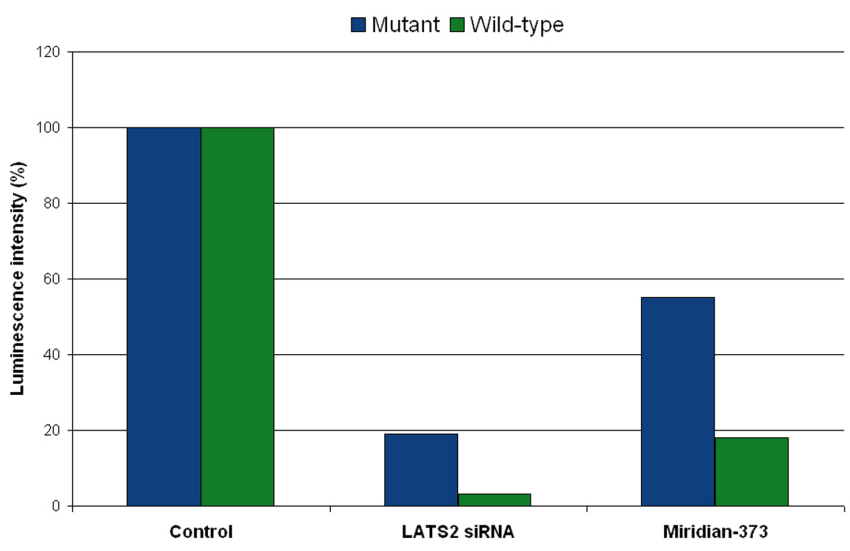

Fig. 8. Result of luciferase measurement assay. It is shown that luciferase activity is down-regulated in both NTera2 cells subjected to LATS2 siRNA and miridian-373. Luciferase activity is also partly down-regulated in cells with a mutant construct of LATS2, which may be due to the partial homology between the siRNA or miridian and LATS2 sequence in the construct. The results are based on six parallel experiments (96 wells) for each condition tested. Standard deviations were: for controls: 10,015 and $0,014)$, LATS2 siRNA (0,079 and 0,058), miridian-373 (0,057 and 0,025) mutant and wild-type respectively.

miR-371-3 in cell cycle and cisplatin sensitivity of GCC cell lines. As a consequence of the poor transfectability of the GCC cell lines, a lentiviral construct was designed to monitor the manipulation of miR levels. In the lentiviral construct, the luciferase reporter is linked to the 3' untranslated region (UTR) of LATS2. In addition, the construct contains a selection marker to allow for stable integration in the GCC cell genome. Its functionality was demonstrated using oligonucleotides for a miR-373 mimic (meridian-373) and a siRNA directed to the 3'UTR. These oligos were introduced into the cells by transient transfection and their consequence on luciferase activity was measured. Both the meridian-373 and the LATS2 siRNA caused strong reduction of the luciferase activity (Fig. 8), and thus demonstrate the sensitivity of the reporter system. Recently an alternative reporter system based on a retroviral construct (miRSens) was published (Beillard et al., 2012). In this vector, the Renilla luciferase gene is also linked to the LATS2 3'UTR and the Firefly luciferase is needed for normalization in the absence of a selection marker. Following introduction of a retroviral vector causing expression of miR-373, the authors could demonstrate reduction of the luciferase activity as a result of the targeting of the LATS2 3"UTR (Beillard et al., 2012). Both approaches are well suited to monitor the consequence of introduction of exogenous miR, but it remains to be established whether these reporters can monitor changes in endogenous levels of miR following cell differentiation or other treatments.

\section{Cisplatin sensitivity in GCC and proposed model for involvement of microRNA clusters 371-3 and 302/367}

Recently, involvement of some miRs (miR-193b and miR-320) in resistancy/sensitivity to platinum agents in ovarian cancer cell lines has been reported (Ziliak et al., 2012). Platinum agents are main chemotherapeutic agents used in the treatment of cancers (Williams and Whitehouse, 1979). As mentioned, ES cell-specific miRs have a central role in $G_{1}-S$ transition and promotion of cel- 
lular proliferation. EC cells, similarly to ES cells, have a short $G_{1}-S$ transition and are therefore highly responsive to cisplatin-based chemotherapy. Indeed, NTera-2 cells respond to cisplatin as well. The level of expression of the miR-302 cluster in NTera- 2 cells is relatively high (Gillis et al., 2007). This causes sensitivity to DNAdamaging agents such as cisplatin (Fig. 3). Our model predicts that suppression of the two ES cell miRs, miR-302 and miR-371-3 cluster in GCC cell lines will cause longer $G_{1}-S$ transition due to higher level of Cyclin D1 and LATS2 expression respectively. This will leads to suppression of CDK inhibitors and consequently will induce resistance to cisplatin in these cells.

\section{Detection of miR-373, miR-302c and 367 clusters in serum of patients with GCC}

Recently, there has been an enormous interest in investigating circulating miRs in blood plasma/serum as potential biomarkers for early disease, including cancer. In multiple reports, detection of cancer-specific miRs in serum of cancer patients has been reported (Chen et al., 2008, Morimura et al., 2011, Zahm et al., 2011). Currently, serum markers such as alpha feto-protein (AFP) and human Chorionic Gonadotropine (hCG) are predominantly informative for initial diagnosis as well as follow up of GCC, predominalty related to $\mathrm{YS}$ and choriocarcinoma components, respectively (Horwich et al., 2006). However, no informative serum marker for SE and EC exist, which is highly relevant, because of the distribution of these components in GCC overall, and their stem cell characteristics and behavior. Therefore, the necessity for new serum markers in order to detect and follow-up the other histological component of GCC is apparent. Interestingly, a case report (Murray et al., 2011) showed the feasibility of measuring serum levels of the miR-371-3 and miR-302 clusters in a single patient. In addition, a decline of these miR level in serum of GCC patients after surgical removal of the (stage I) GCC was shown (Belge et al., 2012). A subsequent study (Murray and Coleman, 2012) demonstrated elevation of these miR clusters in serum of multiple patients at the time of initial diagnosis with different histological subtypes. These findings open new avenues for diagnosis and follow-up the other mentioned cancer patients as well.

The finding of stable extracellular miRs in serum/plasma and other body fluid types suggests the possibility of their involvement in mediating cell-cell communication. This could imply that miRs convey specific information and therefore only some cellular miRs are exported or released from cells in response to biological stimuli. In addition, it is shown that cells release a significant number of
RNA-binding proteins into the culture medium and one of them, nucleophosmin 1 (NPM1), can protect miRs from degradation. There is no evidence yet that miR containing complexes are taken up by other cells, although vesicles containing miRs are reported to be taken up by cells. It is possible that miRs outside vesicles, complexed with proteins, could be targeted to specific cell surface receptors (Wang et al., 2010).

It is controversial whether miRs circulate freely or are encapsulated in micro-vesicles, particularly exosomes; in other words if their transport is active or passive. It is suggested that extracellular miRs are bound to Ago proteins and Ago2 in particular. It is shown that miRs remained stable in the cell lysates for at least 2 month meaning that Ago2/miR complexes are highly nuclease/ protease resistant. The $\mathrm{miR} / \mathrm{Ago} 2$ complexes are released from the cells upon necrosis or apoptosis (Turchinovich et al., 2011). This has been confirmed by another study in which it is shown that although some circulating miRs are vesicle-associated, $90 \%$ of miRs are present in a non-membrane-bound form consistent with a ribonucleoprotein complex which is identified as Ago2-miR complex (Arroyo et al., 2011). However, it is reported that the majority of miRs detectable in serum and saliva is concentrated in exosomes (Gallo et al., 2012). In this study it is shown that the concentration of miRs is consistently higher in the exosome pellet compared to the exosome-depleted supernatant. The reason for this discrepancy is unclear but could be due to differences in isolation exosomes or differences between plasma and serum.

To confirm the findings in GCC patients, we aimed to detect the serum level of the mentioned miR clusters in a series of GCC patients at stage I and higher (i.e., metastatic disease). As a pilot study, we tested the serum level of miRs 373, 302c and 200c (as control) in a limited number of cases. The miR-200c is reported to be involved in metastasis of epithelial cancers (Hurteau et al., 2007) and is not specific for GCC. Serum samples included in our study were high stage (stage II and higher) GCC serum samples, stage I GCC serum samples and inflammatory serum samples as controls (10 sample of each). Indeed a higher level of miRs was detected in serum of GCC patients compared to control samples, correlated with stage of presentation of the disease (Fig. 9). However, there are technical limitations in all studies reported, related to low RNA recovery from serum, and issues of normalization (done based on volume of $R N U 6 B$ ). To solve these problems, we developed together with Applied Biosystems (part of Life Technologies) a complete pipeline for detection of miRs in body fluids based on a magnetic-bead based purification and qPCR quantitation.
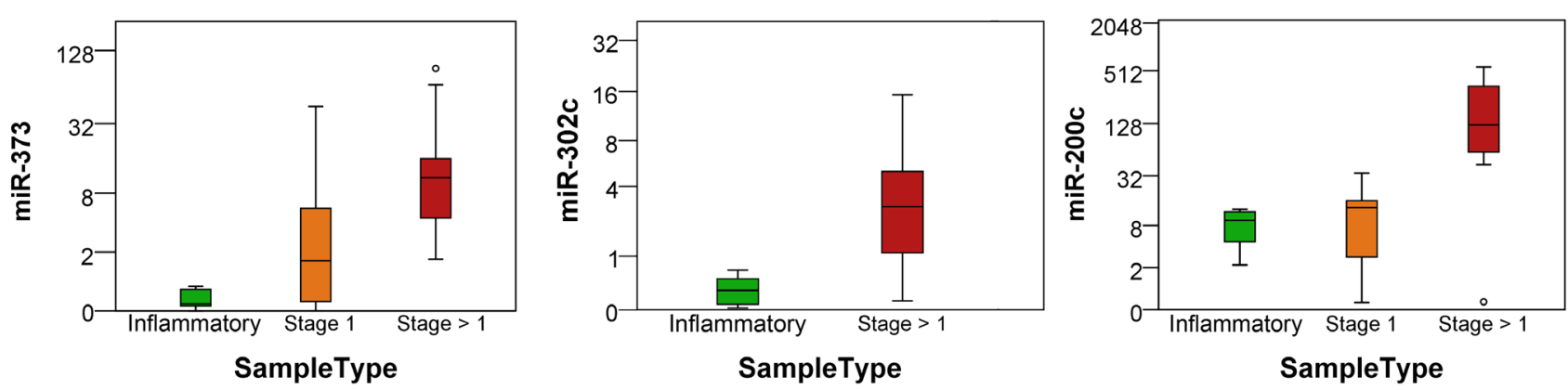

Fig. 9. Results of level of microRNA (miR) in serum of patients with stage I and higher stage germ cell cancer (GCC). miR-373 and miR-200c show the highest levels in higher stage GCC and less expression level in stage I samples while the expression levels are very low in case of inflammation. The miR-302c was measured in inflammatory samples and high stage tumours showing higher expression level in high stage GCC. 


\section{Correlation between the level of miR-302/367 and miR- 371-3 cluster between the tumors and the serum of the same GCC}

To investigate whether the pattern of miRs is serum correlates with the pattern observed in the matched primary tumors, a series of 10 GCC cases (including stage I and higher) were investigated. Statistical analysis showed no correlation between the level of miRs within the tumor and matched serum samples (statistical analysis not shown). This suggests that specific (active) mechanisms are involved in this process.

\section{Methylation status of the promoter of miR-371-3 in GCC:}

Gene function in cancer cells can be disrupted either through genetic alteration, directly by mutation, deletion or amplification (Baylin et al., 2001). However, no such anomalies have been found so far in a series of 242 GCC regarding the miR-371-3 and miR-302/367 clusters. Alternatively, this can be the result of epigenetic changes, including DNA methylation. This is a major epigenetic modification of the genome that regulates crucial aspects of its function and allows cells to lock genes in the "off" position. Disruption of DNA methylation associated with specific imprinted genes is a common feature of human cancers (Plass and Soloway, 2002). Hypermethylation of promoter regions has been observed for several anti-oncogenes and hypomethylation has been reported for some proto-oncogenes. A genome-wide survey has revealed that the overall degree of methylation in SE is lower than in nonseminoma tissues (Smiraglia et al., 2002). Methylation of genomic DNA is performed by DNA methyltransferases that transfer methyl groups to cytosine residues. The five genes known to encode DNA

A

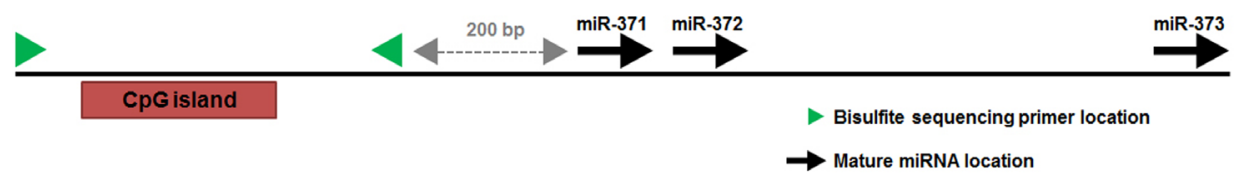

B

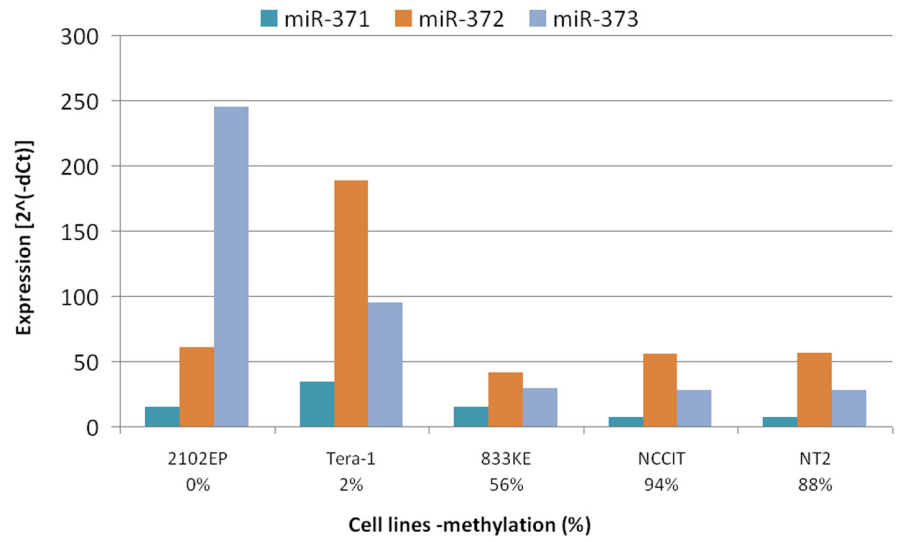

Fig. 10. (A) miR-371-3 locus. The location of sequencing primers within the promoter of miR-371-3 and the location of mature miRs are shown. (B) Expression pattern of miR-371-3 in comparison to methylation. Percentage of the total number of methylated $C p G$ sites is shown for the cell lines. Expression of miR-373 was strongly, significantly negatively correlated with increasing percentages of methylation (Spearman's $p-0.90, p=0.037$ ). The correlation between expressions of miR-371/2 with methylation was not significant. methyltransferases (DNMT) include DNMT1, DNMT2, DNMT3A, DNMT3B and DNMT3L. Here we mainly discuss DNMT1 which maintains methylation of genomic DNA during DNA replication, thus contributing to stability of gene expression from parental to daughter cells. It has been reported that in the DNMT1-/- mice in which loss of imprinting has been transiently induced, the imprint free stem cells formed in vivo various neoplasms, including a single tumor mimicking seminoma (Holm et al., 2005). Therefore, one hypothesis for the high expression level of miR-371-3 (and possibly miR-302a/367) in GCC, could be that the overall retained demethylation pattern in the precursor cells is involved.

Indeed, changes in miR expression can occur through various mechanisms including chromosomal abnormalities, transcription factor binding and epigenetic alterations. Recent studies have hown that, in cancer, expression of some miR is silenced in as sociation with CpG island hypermethylation (Lujambio et al., 2008, Sharma et al., 2010, Toyota et al., 2008). In order to determine whether the expression pattern of miR-371-3 in GCC (EC, SE and $\mathrm{YS}$ ) is due to the methylation status of the supposed promoter region, we examined the methylation status of $12 \mathrm{CpG}$ sites within the $\mathrm{CpG}$ island of the promoter of miR-371-3 cluster. The CpG island is located 400 bp upstream miR-371 (Fig. 10). Firstly, the methylation status of the promoter of this miR cluster was tested in GCC cell lines using sequencing of bisulfite-treated DNA. A correlation between expression level of miR-371-3 cluster and methylation percentage of the promoter of this cluster was found). The correlation between miR-373 and methylation percentage was significant, however, this correlation for miR-371 and miR-372 was not significant. The reason for this is unclear and needs further investigations. Analysis of micro-dissected GCC samples (EC, SE, YS, and teratoma) showed a different pattern, which needs further investigation (data not shown).

\section{Concluding remarks}

Emerging evidences have revealed the importance of miRs for normal development and maintenance of a multi-cellular organism. It is now proven that formation of ES cells as well as various differentiation lineages is dependent on miRs. The core transcriptional factors and ES cell miRs are linked in a regulatory circuitry that critically regulates both pluripotency and differentiation in human ES cells. These processes are represented in human GCC. In fact the most important reason to study the role of ES cell miRs in GCC is the fact that these cancers mimic embryonic development to a certain extent.

One of the core pluripotency marker in ES cells, OCT3/4, is an informative diagnostic marker for this type of GCC. Detailed investigation on the expression profile of miRs in GCC revealed expression of specific miRs differentially expressed in various histological components. Two of the most informative clusters of miRs were again miR-371-3 and miR-302/367. Interestingly, miR cluster 371- 
3 is involved in inhibition of cellular senescence after oncogenic stress. This explained the presence of wild type P53 in GCC, in contrast to most other solid cancers. High level of miR-371-3 cluster in GCC leads to short $\mathrm{G}_{1}-\mathrm{S}$ transition (via suppression of LATS2) which in turn increases the sensitivity of these tumors to chemotherapy. miR-302 cluster is highly expressed in SE, EC as well as YS. Functional analysis has shown that down-regulation of core pluripotency factors such as OCT3/4 and SOX2, induces reduction of the level of miR-302/367 cluster in an EC cell line NTera-2. Interestingly, OCT3/4 down-regulation in NTera2 induced longer $G_{1}-S$ transition by accumulating more cells in $G_{1}$ phase and less cells is S phase. On the other hand, it is known that differentiated NTera2 cells in which pluripotency factors are down-regulated, show resistance to DNA-damaging agents such as cisplatin. All these together confirm that the link between ES cell miRs and pluripotency markers plays a major role in the pathogenesis of GCC as well as their exceptional sensitivity to DNA damaging agents. Currently, to improve knowledge about the insight roles of these sets of miRs in pathogenesis of GCC, functional analysis on the effect of suppression of these miRs on cisplatin sensitivity as well as cell cycle regulation of GCC cell lines is in process. These findings will shed novel light on normal and malignant germ cell development leading to diagnostic and prognostic implications.

\section{Acknowledgements}

The authors would like to thank Martin Rijlaarsdam (Department of Pathology, Erasmus MC) for his continuous support in analysis of the data and generating the illustrations. Supported by a Grant from the Dutch Cancer Society (KWF: 2006-3607 and 2007-3081).

\section{References}

AKIMOTO, C., UEDA, T., INOUE, K., YAMAOKA, I., SAKARI, M., OBARA, W., FUJIOKA, T., NAGAHARA, A., NONOMURA, N., TSUTSUMI, S. et al., (2010). Testis-specific protein on $Y$ chromosome (TSPY) represses the activity of the androgen receptor in androgen-dependent testicular germ-cell tumors. Proc Natl Acad Sci USA 107: 19891-19896.

ALVAREZ-GARCIA, I. and MISKA, E.A. (2005). MicroRNA functions in animal development and human disease. Development 132: 4653-4662.

ANOKYE-DANSO, F., TRIVEDI, C.M., JUHR, D., GUPTA, M., CUI, Z., TIAN, Y., ZHANG, Y., YANG, W., GRUBER, P.J., EPSTEIN, J.A. et al., (2011). Highly efficient miRNA-mediated reprogramming of mouse and human somatic cells to pluripotency. Cell Stem Cell 8: 376-388.

ARROYO, J.D., CHEVILLET, J.R., KROH, E.M., RUF, I.K., PRITCHARD, C.C., GIBSON, D.F., MITCHELL, P.S., BENNETT, C.F., POGOSOVA-AGADJANYAN, E.L., STIREWALT, D.L. et al., (2011). Argonaute2 complexes carry a population of circulating microRNAs independent of vesicles in human plasma. Proc Natl Acad Sci USA 108: 5003-5008.

BARROSO-DELJESUS, A., ROMERO-LOPEZ, C., LUCENA-AGUILAR, G., MELEN, G.J., SANCHEZ, L., LIGERO, G., BERZAL-HERRANZ, A. and MENENDEZ, P. (2008). Embryonic stem cell-specific miR302-367 cluster: human gene structure and functional characterization of its core promoter. Mol Cell Biol 28: 6609-6619.

BAYLIN, S.B., ESTELLER, M., ROUNTREE, M.R., BACHMAN, K.E., SCHUEBEL, K. and HERMAN, J.G. (2001). Aberrant patterns of DNA methylation, chromatin formation and gene expression in cancer. Hum Mol Genet 10: 687-692.

BEILLARD, E., ONG, S.C., GIANNAKAKIS, A., GUCCIONE, E., VARDY, L.A. and VOORHOEVE, P.M. (2012). miR-Sens--a retroviral dual-luciferase reporter to detect microRNA activity in primary cells. RNA 18: 1091-1100.

BELGE, G., DIECKMANN, K.P., SPIEKERMANN, M., BALKS, T. and BULLERDIEK, J. (2012). Serum levels of microRNAs miR-371-3: a novel class of serum biomarkers for testicular germ cell tumors? Eur Urol 61: 1068-1069.

BERNSTEIN, E., KIM, S.Y., CARMELL, M.A., MURCHISON, E.P., ALCORN, H., LI, M.Z., MILLS, A.A., ELLEDGE, S.J., ANDERSON, K.V. and HANNON, G.J. (2003).
Dicer is essential for mouse development. Nat Genet 35: 215-217.

BOIANI, M., KEHLER, J. and SCHOLER, H.R. (2004). Activity of the germlinespecific Oct4-GFP transgene in normal and clone mouse embryos. Methods Mol Biol 254: 1-34.

BOYER, L.A., LEE, T.I., COLE, M.F., JOHNSTONE, S.E., LEVINE, S.S., ZUCKER, J.P., GUENTHER, M.G., KUMAR, R.M., MURRAY, H.L., JENNER, R.G. et al., (2005). Core transcriptional regulatory circuitry in human embryonic stem cells. Cell 122: 947-956.

CAIRO, S., WANG, Y., DE REYNIES, A., DUROURE, K., DAHAN, J., REDON, M.J., FABRE, M., MCCLELLAND, M., WANG, X.W., CROCE, C.M. et al., (2010). Stem cell-like micro-RNA signature driven by Myc in aggressive liver cancer. Proc Natl Acad Sci USA 107: 20471-20476.

CALABRESE, J.M., SEILA, A.C., YEO, G.W. and SHARP, P.A. (2007). RNA sequence analysis defines Dicer's role in mouse embryonic stem cells. Proc Natl Acad Sci USA 104: 18097-18102.

CAMPAYO, M., NAVARRO, A., VINOLAS, N., DIAZ, T., TEJERO, R., GIMFERRER, J.M., MOLINS, L., CABANAS, M.L., RAMIREZ, J., MONZO, M. et al., (2013). Low miR-145 and high miR-367 are associated with unfavorable prognosis in resected NSCLC. 41: 1172-1178.

CANELA, N., RODRIGUEZ-VILARRUPLA, A., ESTANYOL, J.M., DIAZ, C., PUJOL, M.J., AGELL, N. and BACHS, O. (2003). The SET protein regulates G2/M transition by modulating cyclin B-cyclin-dependent kinase 1 activity. J Biol Chem 278: 1158-1164.

CARD, D.A., HEBBAR, P.B., LI, L., TROTTER, K.W., KOMATSU, Y., MISHINA, Y. and ARCHER, T.K. (2008). Oct4/Sox2-regulated miR-302 targets cyclin D1 in human embryonic stem cells. Mol Cell Biol 28: 6426-6438.

CHEN, C.Z. (2005). MicroRNAs as oncogenes and tumor suppressors. N Engl J Med 353: 1768-1771.

CHEN, X., BA, Y., MA, L., CAI, X., YIN, Y., WANG, K., GUO, J., ZHANG, Y., CHEN, J., GUO, X. et al., (2008). Characterization of microRNAs in serum: a novel class of biomarkers for diagnosis of cancer and other diseases. Cell Res 18: 997-1006.

DEJONG, J., STOOP, H., GILLIS, A.J., VAN GURP, R.J., VAN DE GEIJN, G.J., BOER, M., HERSMUS, R., SAUNDERS, P.T., ANDERSON, R.A., OOSTERHUIS, J.W. et al., (2008). Differential expression of SOX17 and SOX2 in germ cells and stem cells has biological and clinical implications. $J$ Pathol 215: 21-30.

FAREH, M., TURCHI, L., VIROLLE, V., DEBRUYNE, D., ALMAIRAC, F., DE-LAFOREST DIVONNE, S., PAQUIS, P., PREYNAT-SEAUVE, O., KRAUSE, K.H., CHNEIWEISS, H. et al., (2012). The miR 302-367 cluster drastically affects self-renewal and infiltration properties of glioma-initiating cells through CXCR4 repression and consequent disruption of the SHH-GLI-NANOG network. Cell Death Differ 19: 232-244.

GALLO, A., TANDON, M., ALEVIZOS, I. and ILLEI, G.G. (2012). The majority of microRNAs detectable in serum and saliva is concentrated in exosomes. PLOS One 7: e30679.

GILLIS, A.J., STOOP, H.J., HERSMUS, R., OOSTERHUIS, J.W., SUN, Y., CHEN, C., GUENTHER, S., SHERLOCK, J., VELTMAN, I., BAETEN, J. et al., (2007). High-throughput microRNAome analysis in human germ cell tumours. $J$ Pathol 213: 319-328.

HAJKOVA, P., ERHARDT, S., LANE, N., HAAF, T., EL-MAARRI, O., REIK, W., WALTER, J. and SURANI, M.A. (2002). Epigenetic reprogramming in mouse primordial germ cells. Mech Dev 117: 15-23.

HANAHAN, D. and WEINBERG, R.A. (2000). The hallmarks of cancer. Cell100:57-70.

HE, S., NAKADA, D. and MORRISON, S.J. (2009). Mechanisms of stem cell selfrenewal. Annu Rev Cell Dev Biol 25: 377-406.

HOLM, T.M., JACKSON-GRUSBY, L., BRAMBRINK, T., YAMADA, Y., RIDEOUT, W.M., $3 R D$ and JAENISCH, R. (2005). Global loss of imprinting leads to widespread tumorigenesis in adult mice. Cancer Cell 8: 275-285.

HONG, Y. and STAMBROOK, P.J. (2004). Restoration of an absent G1 arrest and protection from apoptosis in embryonic stem cells after ionizing radiation. Proc Natl Acad Sci USA 101: 14443-14448.

HORWICH, A., SHIPLEY, J. and HUDDART, R. (2006). Testicular germ-cell cancer. Lancet 367: 754-765.

HUANG, Q., GUMIREDDY, K., SCHRIER, M., LE SAGE, C., NAGEL, R., NAIR, S., EGAN, D.A., LI, A., HUANG, G., KLEIN-SZANTO, A.J. et al., (2008). The microRNAs miR-373 and miR-520c promote tumour invasion and metastasis. Nat Cell Biol 10: 202-210. 
HUANGFU, D., MAEHR, R., GUO, W., EIJKELENBOOM, A., SNITOW, M., CHEN, A.E. and MELTON, D.A. (2008). Induction of pluripotent stem cells by defined factors is greatly improved by small-molecule compounds. Nat Biotechnol 26: 795-797.

HURTEAU, G.J., CARLSON, J.A., SPIVACK, S.D. and BROCK, G.J. (2007). Overexpression of the microRNA hsa-miR-200c leads to reduced expression of transcription factor 8 and increased expression of E-cadherin. Cancer Res 67: 7972-7976.

HUYGHE, E., PLANTE, P. and THONNEAU, P.F. (2007). Testicular cancer variations in time and space in Europe. Eur Urol 51: 621-628.

JAENISCH, R. and YOUNG, R. (2008). Stem cells, the molecular circuitry of pluripotency and nuclear reprogramming. Cell 132: 567-582.

JUDSON, R.L., BABIARZ, J.E., VENERE, M. and BLELLOCH, R. (2009). Embryonic stem cell-specific microRNAs promote induced pluripotency. Nat Biotechnol 27: 459-461.

KANAI-AZUMA, M., KANAI, Y., GAD, J.M., TAJIMA, Y., TAYA, C., KUROHMARU, M., SANAI, Y., YONEKAWA, H., YAZAKI, K., TAM, P.P. et al., (2002). Depletion of definitive gut endoderm in Sox17-null mutant mice. Development 129:2367-2379.

KANELLOPOULOU, C., MULJO, S.A., KUNG, A.L., GANESAN, S., DRAPKIN, R., JENUWEIN, T., LIVINGSTON, D.M. and RAJEWSKY, K. (2005). Dicer-deficient mouse embryonic stem cells are defective in differentiation and centromeric silencing. Genes Dev 19: 489-501.

KARP, X. and AMBROS, V. (2005). Developmental biology. Encountering microRNAs in cell fate signaling. Science 310: 1288-1289.

KERSEMAEKERS, A.M., MAYER, F., MOLIER, M., VAN WEEREN, P.C., OOSTERHUIS, J.W., BOKEMEYER, C. and LOOIJENGA, L.H. (2002). Role of P53 and MDM2 in treatment response of human germ cell tumors. J Clin Oncol 20: 1551-1561.

KORKOLA, J.E., HOULDSWORTH, J., CHADALAVADA, R.S., OLSHEN, A.B., DOBRZYNSKI, D., REUTER, V.E., BOSL, G.J. and CHAGANTI, R.S. (2006). Down-regulation of stem cell genes, including those in a 200-kb gene cluster at $12 \mathrm{p} 13.31$, is associated with in vivo differentiation of human male germ cell tumors. Cancer Res 66: 820-827.

KUCKENBERG, P., PEITZ, M., KUBACZKA, C., BECKER, A., EGERT, A., WARDELMANN, E., ZIMMER, A., BRUSTLE, O. and SCHORLE, H. (2011). Lineage conversion of murine extraembryonic trophoblast stem cells to pluripotent stem cells. Mol Cell Biol 31: 1748-1756.

LANDTHALER, M., YALCIN, A. and TUSCHL, T. (2004). The human DiGeorge syndrome critical region gene 8 and lts $D$. melanogaster homolog are required for miRNA biogenesis. Curr Biol 14: 2162-2167.

LAWRIE, C.H., CHI, J., TAYLOR, S., TRAMONTI, D., BALLABIO, E., PALAZZO, S., SAUNDERS, N.J., PEZZELLA, F., BOULTWOOD, J., WAINSCOAT, J.S. et al., (2009). Expression of microRNAs in diffuse large B cell lymphoma is associated with immunophenotype, survival and transformation from follicular lymphoma. $J$ Cell Mol Med 13: 1248-1260.

LEE, K.H., GOAN, Y.G., HSIAO, M., LEE, C.H., JIAN, S.H., LIN, J.T., CHEN, Y.L. and LU, P.J. (2009). MicroRNA-373 (miR-373) post-transcriptionally regulates large tumor suppressor, homolog 2 (LATS2) and stimulates proliferation in human esophageal cancer. Exp Cell Res 315: 2529-2538.

LEE, R.C., FEINBAUM, R.L. and AMBROS, V. (1993). The C. elegans heterochronic gene lin-4 encodes small RNAs with antisense complementarity to lin-14. Cell 75: 843-854.

LEE, Y., AHN, C., HAN, J., CHOI, H., KIM, J., YIM, J., LEE, J., PROVOST, P., RADMARK, O., KIM, S. et al., (2003). The nuclear RNase III Drosha initiates microRNA processing. Nature 425: 415-419.

LIM, L.P., LAU, N.C., WEINSTEIN, E.G., ABDELHAKIM, A., YEKTA, S., RHOADES, M.W., BURGE, C.B. and BARTEL, D.P. (2003). The microRNAs of Caenorhabditis elegans. Genes Dev 17: 991-1008.

LIN, S.L., CHANG, D.C., CHANG-LIN, S., LIN, C.H., WU, D.T., CHEN, D.T. and YING, S.Y. (2008). Mir-302 reprograms human skin cancer cells into a pluripotent ES-cell-like state. RNA 14: 2115-2124.

LIU, C., KELNAR, K., LIU, B., CHEN, X., CALHOUN-DAVIS, T., LI, H., PATRAWALA, L., YAN, H., JETER, C., HONORIO, S. et al., (2011). The microRNA miR-34a inhibits prostate cancer stem cells and metastasis by directly repressing CD44. Nat Med 17: 211-215.

LIU, C. and TANG, D.G. (2011). MicroRNA regulation of cancer stem cells. Cancer Res 71: 5950-5954.

LOH, Y.H., WU, Q., CHEW, J.L., VEGA, V.B., ZHANG, W., CHEN, X., BOURQUE, G., GEORGE, J., LEONG, B., LIU, J. et al., (2006). The Oct4 and Nanog tran- scription network regulates pluripotency in mouse embryonic stem cells. Nat Genet 38: 431-440.

LOOIJENGA, L.H., GILLIS, A.J., STOOP, H., HERSMUS, R. and OOSTERHUIS, J.W. (2007). Relevance of microRNAs in normal and malignant development, including human testicular germ cell tumours. Int J Andro/30: 304-314; discussion 314-315.

LOOIJENGA, L.H., HERSMUS, R., GILLIS, A.J., PFUNDT, R., STOOP, H.J., VAN GURP, R.J., VELTMAN, J., BEVERLOO, H.B., VAN DRUNEN, E., VAN KESSEL, A.G. et al., (2006). Genomic and expression profiling of human spermatocytic seminomas: primary spermatocyte as tumorigenic precursor and DMRT1 as candidate chromosome 9 gene. Cancer Res 66: 290-302.

LOOIJENGA, L.H., STOOP, H., DE LEEUW, H.P., DE GOUVEIA BRAZAO, C.A., GILLIS, A.J., VAN ROOZENDAAL, K.E., VAN ZOELEN, E.J., WEBER, R.F., WOLFFENBUTTEL, K.P., VAN DEKKEN, H. et al., (2003). POU5F1 (OCT3/4) identifies cells with pluripotent potential in human germ cell tumors. Cancer Res 63: 2244-2250.

LU, R., MARKOWETZ, F., UNWIN, R.D., LEEK, J.T., AIROLDI, E.M., MACARTHUR, B.D., LACHMANN, A., ROZOV, R., MA'AYAN, A., BOYER, L.A. et al., (2009) Systems-level dynamic analyses of fate change in murine embryonic stem cells. Nature 462: 358-362.

LUJAMBIO, A., CALIN, G.A., VILLANUEVA, A., ROPERO, S., SANCHEZ-CESPEDES, M., BLANCO, D., MONTUENGA, L.M., ROSSI, S., NICOLOSO, M.S., FALLER, W.J. et al., (2008). A microRNA DNA methylation signature for human cancer metastasis. Proc Natl Acad Sci USA 105: 13556-13561.

LUND, E., GUTTINGER, S., CALADO, A., DAHLBERG, J.E. and KUTAY, U. (2004) Nuclear export of microRNA precursors. Science 303: 95-98.

MARSON, A., LEVINE, S.S., COLE, M.F., FRAMPTON, G.M., BRAMBRINK, T, JOHNSTONE, S., GUENTHER, M.G., JOHNSTON, W.K., WERNIG, M., NEWMAN, J. et al., (2008). Connecting microRNA genes to the core transcriptional regulatory circuitry of embryonic stem cells. Cell 134: 521-533.

MASTERS, J.R. and KOBERLE, B. (2003). Curing metastatic cancer: lessons from testicular germ-cell tumours. Nat Rev Cancer 3: 517-525

MASUI, S., NAKATAKE, Y., TOYOOKA, Y., SHIMOSATO, D., YAGI, R., TAKAHASHI, K., OKOCHI, H., OKUDA, A., MATOBA, R., SHAROV, A.A. et al., (2007). Pluripotency governed by Sox 2 via regulation of Oct $3 / 4$ expression in mouse embryonic stem cells. Nat Cell Biol 9: 625-635.

MCIVER, S.C., STANGER, S.J., SANTARELLI, D.M., ROMAN, S.D., NIXON, B. and MCLAUGHLIN, E.A. (2012). A unique combination of male germ cell miRNAs coordinates gonocyte differentiation. PLoS One 7: e35553.

MCLAREN, A. (2003). Primordial germ cells in the mouse. Dev Biol 262: 1-15.

MEDEIROS, L.A., DENNIS, L.M., GILL, M.E., HOUBAVIY, H., MARKOULAKI, S., FU, D., WHITE, A.C., KIRAK, O., SHARP, P.A., PAGE, D.C. et al., (2011). Mir-290-295 deficiency in mice results in partially penetrant embryonic lethality and germ cell defects. Proc Natl Acad Sci USA 108: 14163-14168.

MELTON, C., JUDSON, R.L. and BLELLOCH, R. (2010). Opposing microRNA families regulate self-renewal in mouse embryonic stem cells. Nature 463: 621-626.

MESTDAGH, P., VAN VLIERBERGHE, P., DE WEER, A., MUTH, D., WESTERMANN F., SPELEMAN, F. and VANDESOMPELE, J. (2009). Anovel and universal method for microRNA RT-qPCR data normalization. Genome Biol 10: R64.

MINENO, J., OKAMOTO, S., ANDO, T., SATO, M., CHONO, H., IZU, H., TAKAYAMA, M., ASADA, K., MIROCHNITCHENKO, O., INOUYE, M. et al., (2006). The expression profile of microRNAs in mouse embryos. Nucleic Acids Res 34: 1765-1771.

MITSUI, K., TOKUZAWA, Y., ITOH, H., SEGAWA, K., MURAKAMI, M., TAKAHASHI, K., MARUYAMA, M., MAEDA, M. and YAMANAKA, S. (2003). The homeoprotein Nanog is required for maintenance of pluripotency in mouse epiblast and ES cells. Cell 113: 631-642.

MIYOSHI, N., ISHII, H., NAGANO, H., HARAGUCHI, N., DEWI, D.L., KANO, Y. NISHIKAWA, S., TANEMURA, M., MIMORI, K., TANAKA, F. et al., (2011). Reprogramming of mouse and human cells to pluripotency using mature microRNAs. Cell Stem Cell 8: 633-638.

MORA, P.T., CHANDRASEKARAN, K. and MCFARLAND, V.W. (1980). An embryo protein induced by SV40 virus transformation of mouse cells. Nature 288: 722-724.

MORIMURA, R., KOMATSU, S., ICHIKAWA, D., TAKESHITA, H., TSUJIURA, M., NAGATA, H., KONISHI, H., SHIOZAKI, A., IKOMA, H., OKAMOTO, K. et al., (2011). Novel diagnostic value of circulating miR-18a in plasma of patients with pancreatic cancer. Br J Cancer 105: 1733-1740.

MORIN, R.D., O'CONNOR, M.D., GRIFFITH, M., KUCHENBAUER, F., DELANEY, A. 
PRABHU, A.L., ZHAO, Y., MCDONALD, H., ZENG, T., HIRST, M. et al., (2008). Application of massively parallel sequencing to microRNA profiling and discovery in human embryonic stem cells. Genome Res 18: 610-621.

MURRAY, M.J. and COLEMAN, N. (2012). Testicular cancer: a new generation of biomarkers for malignant germ cell tumours. Nat Rev Urol 9: 298-300.

MURRAY, M.J., HALSALL, D.J., HOOK, C.E., WILLIAMS, D.M., NICHOLSON, J.C. and COLEMAN, N. (2011). Identification of microRNAs From the miR-371 373 and miR-302 clusters as potential serum biomarkers of malignant germ cell tumors. Am J Clin Pathol 135: 119-125.

NAKAGAWA, M., KOYANAGI, M., TANABE, K., TAKAHASHI, K., ICHISAKA, T., AOI, T., OKITA, K., MOCHIDUKI, Y., TAKIZAWA, N. and YAMANAKA, S. (2008). Generation of induced pluripotent stem cells without Myc from mouse and human fibroblasts. Nat Biotechnol 26: 101-106.

NEGRINI, M. and CALIN, G.A. (2008). Breast cancer metastasis: a microRNA story. Breast Cancer Res 10: 203.

NOVOTNY, G.W., BELLING, K.C., BRAMSEN, J.B., NIELSEN, J.E., BORK-JENSEN, J., ALMSTRUP, K., SONNE, S.B., KJEMS, J., RAJPERT-DE MEYTS, E. and LEFFERS, H. (2012). MicroRNA expression profiling of carcinoma in situ cells of the testis. Endocr Relat Cancer 19: 365-379.

OOSTERHUIS, J.W. and LOOIJENGA, L.H. (2005). Testicular germ-cell tumours in a broader perspective. Nat Rev Cancer 5: 210-222.

ORAM, S.W., LIU, X.X., LEE, T.L., CHAN, W.Y. and LAU, Y.F. (2006). TSPY potentiates cell proliferation and tumorigenesis by promoting cell cycle progression in HeLa and NIH3T3 cells. BMC Cancer 6: 154.

OVITT, C.E. and SCHOLER, H.R. (1998). The molecular biology of Oct-4 in the early mouse embryo. Mol Hum Reprod 4: 1021-1031.

PAGE, D.C. (1987). Hypothesis: a Y-chromosomal gene causes gonadoblastoma in dysgenetic gonads. Development 101 Suppl: 151-155.

PAN, G. and THOMSON, J.A. (2007). Nanog and transcriptional networks in embryonic stem cell pluripotency. Cell Res 17: 42-49.

PERRETT, R.M., TURNPENNY, L., ECKERT, J.J., O'SHEA, M., SONNE, S.B., CAMERON, I.T., WILSON, D.I., RAJPERT-DE MEYTS, E. and HANLEY, N.A. (2008). The early human germ cell lineage does not express SOX2 during in vivo development or upon in vitro culture. Biol Reprod 78: 852-858.

PESCE, M. and SCHOLER, H.R. (2001). Oct-4: gatekeeper in the beginnings of mammalian development. Stem Cells 19: 271-278.

PLASS, C. and SOLOWAY, P.D. (2002). DNA methylation, imprinting and cancer. Eur J Hum Genet 10: 6-16.

REINHART, B.J., SLACK, F.J.,BASSON, M.,PASQUINELLI, A.E., BETTINGER, J.C., ROUGVIE, A.E., HORVITZ, H.R. and RUVKUN, G. (2000). The 21-nucleotide let-7 RNA regulates developmental timing in Caenorhabditis elegans. Nature 403: 901-906.

REINHART, B.J., WEINSTEIN, E.G., RHOADES, M.W., BARTEL, B. and BARTEL, D.P. (2002). MicroRNAs in plants. Genes Dev 16: 1616-1626.

RIPPE, V., DITTBERNER, L., LORENZ, V.N., DRIESCHNER, N., NIMZYK, R., SENDT, W., JUNKER, K., BELGE, G. and BULLERDIEK, J. (2010). The two stem cell microRNA gene clusters C19MC and miR-371-3 are activated by specific chromosomal rearrangements in a subgroup of thyroid adenomas. PLoS One 5: e9485.

ROSNER, M.H., VIGANO, M.A., OZATO, K., TIMMONS, P.M., POIRIER, F., RIGBY, P.W. and STAUDT, L.M. (1990). A POU-domain transcription factor in early stem cells and germ cells of the mammalian embryo. Nature 345: 686-692.

SABAPATHY, K., KLEMM, M., JAENISCH, R. and WAGNER, E.F. (1997). Regulation of ES cell differentiation by functional and conformational modulation of $\mathrm{p} 53$. EMBO J 16: 6217-6229.

SCHOLER, H.R., BALLING, R., HATZOPOULOS, A.K., SUZUKI, N. and GRUSS, P. (1989). Octamer binding proteins confer transcriptional activity in early mouse embryogenesis. EMBO J 8: 2551-2557.

SHAH, M.N., DEVESA, S.S., ZHU, K. and MCGLYNN, K.A. (2007). Trends in testicular germ cell tumours by ethnic group in the United States. Int $J$ Androl 30: 206-13, discussion 213-214.

SHARMA, S., KELLY, T.K. and JONES, P.A. (2010). Epigenetics in cancer. Carcinogenesis 31: 27-36.

SKAKKEBAEK, N.E. (1972). Possible carcinoma-in-situ of the testis. Lancet2:516-517. SMIRAGLIA, D.J., SZYMANSKA, J., KRAGGERUD, S.M., LOTHE, R.A., PELTOMAKI, P. and PLASS, C. (2002). Distinct epigenetic phenotypes in seminomatous and nonseminomatous testicular germ cell tumors. Oncogene 21: 3909-3916.

SOLOZOBOVA, V. and BLATTNER, C. (2011). p53 in stem cells. World J Biol Chem 2: $202-14$

STADLER, B., IVANOVSKA, I., MEHTA, K., SONG, S., NELSON, A., TAN, Y., MATHIEU, J., DARBY, C., BLAU, C.A., WARE, C. et al., (2010). Characterization of microRNAs involved in embryonic stem cell states. Stem Cells Dev 19: 935-950.

SUH, M.R., LEE, Y., KIM, J.Y., KIM, S.K., MOON, S.H., LEE, J.Y., CHA, K.Y., CHUNG H.M., YOON, H.S., MOON, S.Y. et al., (2004). Human embryonic stem cells express a unique set of microRNAs. Dev Biol 270: 488-498.

TAKAHASHI, K. and YAMANAKA, S. (2006). Induction of pluripotent stem cells from mouse embryonic and adult fibroblast cultures by defined factors. Cell126:663-676.

TOYOTA, M., SUZUKI, H., SASAKI, Y., MARUYAMA, R., IMAI, K., SHINOMURA Y. and TOKINO, T. (2008). Epigenetic silencing of microRNA-34b/c and B-cell translocation gene 4 is associated with $\mathrm{CpG}$ island methylation in colorectal cancer. Cancer Res 68: 4123-4132.

TREMBLAY, K.D., DUNN, N.R. and ROBERTSON, E.J. (2001). Mouse embryos lacking Smad1 signals display defects in extra-embryonic tissues and germ cel formation. Development 128: 3609-3621.

TURCHINOVICH, A., WEIZ, L., LANGHEINZ, A. and BURWINKEL, B. (2011). Characterization of extracellular circulating microRNA. Nucleic Acids Res 39: 7223-7233.

VAN DER ZWAN, Y.G., STOOP, H. ROSSELLO, F., WHITE, S.J. and LOOIJENGA L.H.J. (2013). Role of epigenetics in the etiology of germ cell cancer. Int. J. Dev. Biol. 57: (doi: 10.1387/ijdb.130017II).

VAN GURP, R.J., OOSTERHUIS, J.W., KALSCHEUER, V., MARIMAN, E.C. and LOOIJENGA, L.H. (1994). Biallelic expression of the H19 and IGF2 genes in human testicular germ cell tumors. J Natl Cancer Inst 86: 1070-1075.

VOORHOEVE, P.M., LE SAGE, C., SCHRIER, M., GILLIS, A.J., STOOP, H., NAGEL, R., LIU, Y.P., VAN DUIJSE, J., DROST, J., GRIEKSPOOR, A. et al., (2006). A genetic screen implicates miRNA-372 and miRNA-373 as oncogenes in testicular germ cell tumors. Cell 124: 1169-1181.

WANG, K., ZHANG, S., WEBER, J., BAXTER, D. and GALAS, D.J. (2010). Export of microRNAs and microRNA-protective protein by mammalian cells. Nucleic Acids Res 38: 7248-7259.

WANG, Y., BASKERVILLE, S., SHENOY, A., BABIARZ, J.E., BAEHNER, L. and BLELLOCH, R. (2008). Embryonic stem cell-specific microRNAs regulate the G1-S transition and promote rapid proliferation. Nat Genet 40: 1478-1483.

WANG, Y., KEYS, D.N., AU-YOUNG, J.K. and CHEN, C. (2009). MicroRNAs in embryonic stem cells. J Cell Physiol 218: 251-255.

WANG, Y., MEDVID, R., MELTON, C., JAENISCH, R. and BLELLOCH, R. (2007). DGCR8 is essential for microRNA biogenesis and silencing of embryonic stem cell self-renewal. Nat Genet 39: 380-385.

WATANABE, T., TAKEDA, A., MISE, K., OKUNO, T., SUZUKI, T., MINAMI, N. and IMAI, H. (2005). Stage-specific expression of microRNAs during Xenopus development. FEBS Lett 579: 318-324.

WERNIG, M., MEISSNER, A., CASSADY, J.P. and JAENISCH, R. (2008). c-Myc is dispensable for direct reprogramming of mouse fibroblasts. Cell Stem Cell2: 10-12.

WHITE, J., STEAD, E., FAAST, R., CONN, S., CARTWRIGHT, P. and DALTON, S. (2005). Developmental activation of the Rb-E2F pathway and establishment of cell cycle-regulated cyclin-dependent kinase activity during embryonic stem cell differentiation. Mol Biol Cell 16: 2018-2027

WIENHOLDS, E. and PLASTERK, R.H. (2005). MicroRNA function in animal development. FEBS Lett 579: 5911-5922.

WILLIAMS, C.J. and WHITEHOUSE, J.M. (1979). Cis-platinum: a new anticancer agent. BrMed J 1: 1689-1691.

WU, N., LIU, X., XU, X., FAN, X., LIU, M., LI, X., ZHONG, Q. and TANG, H. (2011) MicroRNA-373, a new regulator of protein phosphatase 6 , functions as an oncogene in hepatocellular carcinoma. FEBS J 278: 2044-2054.

YAMAGUCHI, S., KURIMOTO, K., YABUTA, Y., SASAKI, H., NAKATSUJI, N., SAITOU M. and TADA, T. (2009). Conditional knockdown of Nanog induces apoptotic cell death in mouse migrating primordial germ cells. Development 136: 4011-4020.

YANG, K., HANDOREAN, A.M. and ICZKOWSKI, K.A. (2009). MicroRNAs 373 and 520c are downregulated in prostate cancer, suppress CD44 translation and enhance invasion of prostate cancer cells in vitro. Int J Clin Exp Pathol 2: 361-369.

YU, J., WANG, F., YANG, G.H., WANG, F.L., MA, Y.N., DU, Z.W. and ZHANG, J.W. (2006). Human microRNA clusters: genomic organization and expression profile 
in leukemia cell lines. Biochem Biophys Res Commun 349: 59-68.

ZAHM, A.M., THAYU, M., HAND, N.J., HORNER, A., LEONARD, M.B. and FRIEDMAN, J.R. (2011). Circulating microRNAis a biomarker of pediatric Crohn disease. J Pediatr Gastroenterol Nutr 53: 26-33.

ZHAO, J.J., YANG, J., LIN, J., YAO, N., ZHU, Y., ZHENG, J., XU, J., CHENG, J.Q. LIN, J.Y. and MA, X. (2009). Identification of miRNAs associated with tumorigenesis of retinoblastoma by miRNA microarray analysis. Childs Nerv Syst 25: 13-20.

ZHAO, Y., YIN, X., QIN, H., ZHU, F., LIU, H., YANG, W., ZHANG, Q., XIANG, C., HOU, P., SONG, Z. et al., (2008). Two supporting factors greatly improve the efficiency of human iPSC generation. Cell Stem Cell 3: 475-479.

ZHENG, G.X., RAVI, A., CALABRESE, J.M., MEDEIROS, L.A., KIRAK, O., DENNIS L.M., JAENISCH, R., BURGE, C.B. and SHARP, P.A. (2011). A latent pro-survival function for the mir-290-295 cluster in mouse embryonic stem cells. PLoS Genet 7: e1002054.

ZILIAK, D., GAMAZON, E.R., LACROIX, B., KYUNG IM, H., WEN, Y. and HUANG, R.S. (2012). Genetic variation that predicts platinum sensitivity reveals the role of miR-193b* in chemotherapeutic susceptibility. Mol Cancer Ther 11:2054-2061.

\section{Further Related Reading, published previously in the Int. J. Dev. Biol.}

The internal structure of embryonic gonads and testis development in Drosophila melanogaster requires scrib, Igl and dlg activity in the soma

Fani Papagiannouli

Int. J. Dev. Biol. (2013) 57: 25-34

Histone hyperacetylation during meiosis interferes with large-scale chromatin remodeling, axial chromatid condensation and sister chromatid separation in the mammalian oocyte

Feikun Yang, Claudia Baumann, Maria M. Viveiros and Rabindranath De La Fuente Int. J. Dev. Biol. (2012) 56: 889-899

Comparative molecular portraits of human unfertilized oocytes and primordial germ cells at 10 weeks of gestation

Ferdinand Diedrichs, Barbara Mlody, Peggy Matz, Heiko Fuchs, Lukas Chavez, Katharina Drewsand James Adjaye

Int. J. Dev. Biol. (2012) 56: 789-797

Regulation of germ cell meiosis in the fetal ovary

Cassy M. Spiller, Josephine Bowles and Peter Koopman

Int. J. Dev. Biol. (2012) 56: 779-787

The germ cell--the mother of all stem cells.

P J Donovan

Int. J. Dev. Biol. (1998) 42: 1043-1050

5 yr ISI Impact Factor $(2011)=2.959$

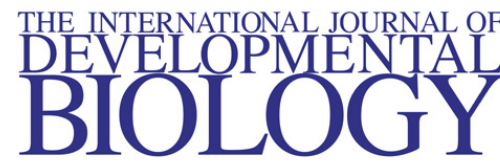

Volume 48 Nos. 5/6 Special issue

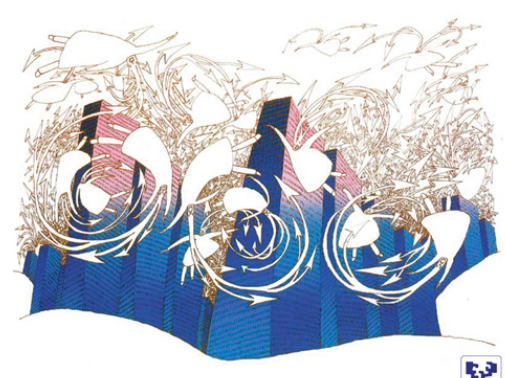

Invasion in cancer and embryonic development
Eis?

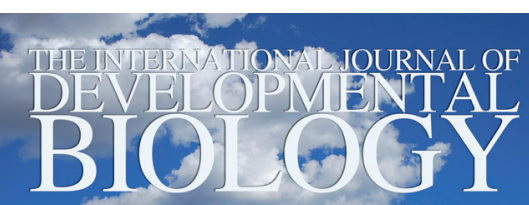

Volume 56 Nos. 10/11/12 - Special Issue
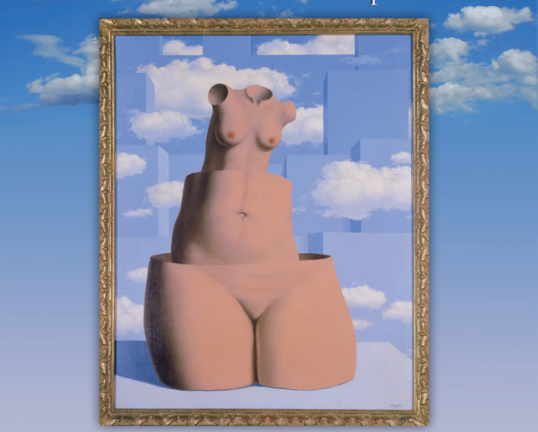

Female Germ Cells in Development \& Tumors
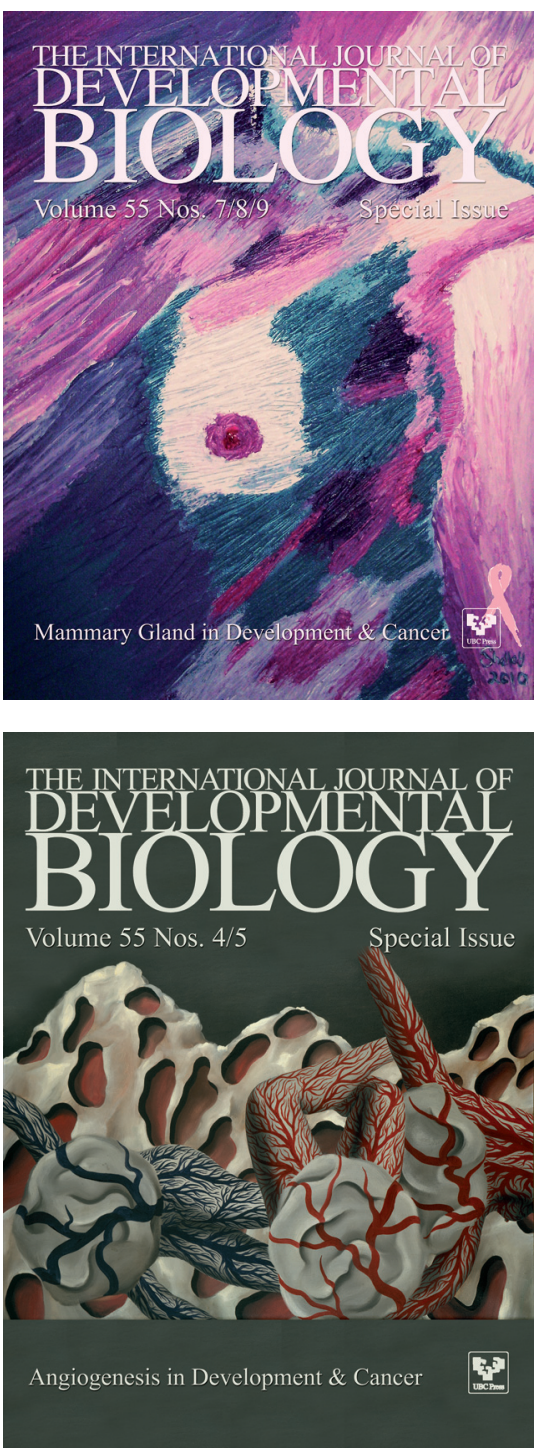